\title{
Failure Risk and the Cross-Section of Hedge Fund Returns
}

\author{
Jung-Min KIM*
}

The views expressed in this paper are those of the author and do not necessarily reflect the official views and policies of the Bank of Korea. When reporting or citing this paper, the author's name should always be stated explicitly.

\footnotetext{
* Economist, Financial \& Monetary Economics Team, Economic Research Institute, the Bank of Korea, E-mail: jungmin.kim@bok.or.kr, Tel: 82-2-759-5424

The author is grateful for helpful comments from Woon Gyu Choi, Kwang Myoung Hwang, Hyung-Kwon Jeong, Jong Ku Kang, Hyun-Jeong Kim, Jieun Lee, Jin-Su Park, and the seminar participants at the Economic Research Institute of the Bank of Korea.

The paper has been accepted for publication in Financial Management.
} 


\section{Contents}

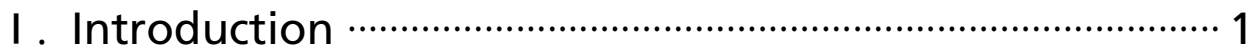

II. The Characteristics of Hedge Fund Failures ………...... 5

2.1. Sample Construction …………………......................................... 5

2.2. Variables included in a Failure Prediction Model ……………........6 6

2.3. Two Different Definitions of Hedge Fund Failure …………............ 9

2.4. Fund Characteristics: Non-Failure Group vs. Failure Group ………1 10

III. Modeling a Probability of Hedge Fund Failure …..... 12

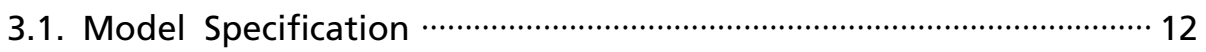

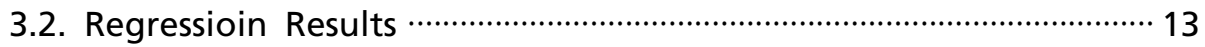

IV. Failure Probability and Hedge Fund Performance $\cdot 15$

4.1. Hedge Fund Portfolios Grouped by Predicted Probability of Failure $\cdots 15$

4.2. Failure Probability and Hedge Fund Performance:

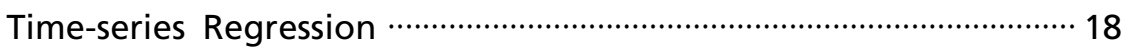

4.3. Failure Probability and Hedge Fund Performance: Panel Regression $\cdots 22$

4.4. The Effect of Each Covariate Variable on Future Hedge Fund Returns $\cdots 24$

4.5. Why do Hedge Funds with High Failure Probability Underperform? $\cdots 26$

V. Robustness Tests ………………………………………...... 28

5.1. Specification of Failure Prediction Model ….................................... 28

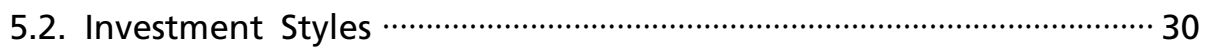

5.3. On-shore Funds vs. Off-shore Funds …............................................ 30

5.4. A Subsample without Extremely Small Funds ……….................... 33

5.5. Sub-period Analysis and Business Cycles ……................................ 33

VI. Conclusion …………………………………………………..... 38

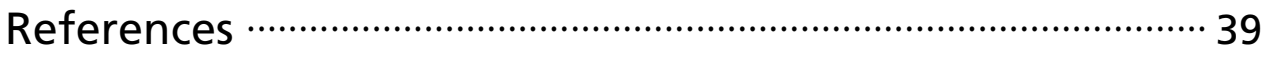




\section{Failure Risk and the Cross-Section of Hedge Fund Returns}

Modeling a hedge fund's probability of failure by a dynamic logit regression, I document that a probability of fund failure has a significantly negative effect on the fund's future returns. A quintile portfolio with highest failure probability underperforms a quintile portfolio with lowest failure probability by $5 \sim 6 \%$ per year from 1997 to 2012. The results are robust to the definition of hedge fund failure and controlling for a large set of risk factors and fund characteristics. Moreover, the negative effect of failure probability on future fund returns is stronger for funds with weak share restrictions.

Keywords: Hedge fund failure, Probability of failure, Share restrictions, Fire-sale

JEL Classification: G23 


\section{I . Introduction}

Hedge funds are largely unregulated and their operations lack transparency. As a result, both regulators and hedge fund investors are concerned about hedge funds' potential failure. Prior literature (e.g., Brown, Goetzmann and Park (2001), Baquero, Horst and Verbeek (2005), Malkiel and Saha (2005), Chan, Getmansky, Haas and Lo (2006), Grecu, Malkiel and Saha (2007), Liang and Park (2010)) focuses on the preconditions of hedge fund failure. I extend the previous literature by systematically investigating how a probability of fund failure affects future hedge fund returns.

Hedge funds with high probability of failure could earn higher future fund returns. These hedge funds with high failure risk might have higher exposures to macro-level systematic risks, which on average lead to higher future fund returns.1) Furthermore, fund managers in these funds with high failure probability may have an incentive to take on extreme risk, which could also lead to higher expected fund returns.

Alternatively, hedge funds with high probability of failure could earn lower future fund returns. Hedge fund failures are often characterized by poor performance over time following investor withdrawals (e.g., Liang and Park (2010)). As a hedge fund becomes increasingly concerned with investors withdrawing their capital due to poor performance, it may be forced to change its investment policy. In particular, it has to increase its positions in liquid assets in order to meet rising redemption requests. To become more liquid, a fund may be forced to sell off some illiquid assets at fire-sale prices. This in turn can be costly and hence reduce fund performance. Therefore, this paper examines empirically how failure probability and future fund returns are linked in the cross-section of hedge funds.

In this paper, I use the TASS hedge fund database. TASS assigns each defunct hedge fund, who stops reporting to the database, to one of seven drop reasons.2)

1) See Bali, Brown, and Caglayan (2011, 2012 and 2014) for a positive link between exposures to macro-level systematic risks and future hedge fund returns

2) The seven drop reasons are as follows: (1) liquidated, (2) no longer reporting to TASS, (3) TASS has been unable to contact the manager for updated information, (4) closed to new investment, (5) merged into another entity, (6) dormant, and (7) unknown. 
Among the seven drop reasons, "liquidation" seems to be the best candidate for defining a hedge fund failure. However, prior literature suggests that liquidation does not necessarily mean failure and part of the other defunct funds should be considered as failure (e.g., Liang and Park (2010)). Therefore, I consider two different definitions of hedge fund failure. The first definition of failure is liquidation. The second definition of failure follows Liang and Park (2010) (hereafter, LP-failure) where failure is defined as follows: (1) once listed in a database but stopped reporting, (2) negative average rate of return for the last 6 months, and (3) decreased assets under management (AUM) for the last 12 months. Interestingly, only 541 funds (out of 1,205 liquidated funds or out of 1,041 failed funds by LP-failure) are classified as failed funds by both definitions. Since one definition of fund failure does not include the other definition of fund failure, the application of both definitions of fund failure would be a good compromise for testing robustness.

I first examine the predictability of hedge fund failures by employing a dynamic logit model in a manner similar to Shumway (2001) and Campbell, Hilscher and Szilagyi (2008), who apply the model to forecast corporate failures based on accounting and stock market variables. Motivated by prior literature and economic intuition, I propose several covariates for the failure prediction model (e.g., past performance, fund flows, risks, fund size, and share restrictions). Overall, poor past performance, fund outflows, higher risk-taking, smaller fund size, and weak share restrictions increase a probability of hedge fund failure.

As a next step, I examine how a hedge fund's failure probability affects its future returns. For the performance test, I remove the last two monthly returns of failed funds to mitigate a concern that a potential negative link between failure probability and future hedge fund returns could be driven by large negative returns of failed funds in failure months. In order to obtain the predicted failure probability, I estimate the failure prediction model every month using a rolling-window approach based on only prior information, instead of using the parameter estimates obtained from the full-sample results. This allows me to perform an out-of-sample prediction analysis and implement a trading strategy. To see whether a fund's failure probability is helpful to predict the fund's future 
returns, I sort hedge funds into quintiles by their predicted failure probability. By examining the monthly time-series returns of quintile portfolios from 1997 to 2012, I find that a quintile group with the highest failure probability significantly underperforms a quintile group with the lowest failure probability by $0.49 \%$ per month with $\mathrm{t}$-stat $=5.50$ (where failure means liquidation) or $0.41 \%$ per month with $\mathrm{t}$-stat $=3.98$ (where failure is defined by LP-failure) after adjusting for exposures to more than ten hedge fund risk factors.

To be robust, I also estimate a panel regression with two-way (fund and month) clustered errors to examine how a hedge fund's probability of failure affects its future returns. A panel regression allows me to control for any effect of a hedge fund's fund-level variables on its future returns. In addition, the two-way clustered errors suggested by Petersen (2009) ensure a robust standard error. ${ }^{3)}$ Results confirm a significantly negative link between failure probability and future fund returns even after controlling for more than ten fund-level variables. Further tests suggest that the negative effect of failure probability on future fund returns is not explained by the effect of any single variable included in the failure prediction model.

Why do hedge funds perform poorly when their failure risk is high? According to the results from a failure prediction model, a high probability of hedge fund failure is characterized by fund outflows due to poor performance. To meet increasing redemption requests, the fund is forced to sell off some assets, potentially at fire-sale prices, which in turn would decrease fund performance. Thus, if there is a negative link between failure probability and future hedge fund returns, the negative effect of failure probability on future hedge fund returns should be heightened for funds with weak share restrictions. Using double sorts, I show that a return spread by failure probability within the funds with weak share restrictions is $3 \sim 4$ times higher than a return spread by failure probability within the funds with strong share restrictions. ${ }^{4)}$

3) Petersen (2009) stipulates that the estimated standard errors of panel-regression parameters are downward biased (as a result, t-values are overstated) when researchers treat the panel observations as independent in the presence of firm effects. Hence, I compute t-values using the standard errors clustered by both hedge funds and calendar months.

4) Strong share restrictions are defined as having a lockup and requiring at least 30-day redemption notice periods, while weak share restrictions are defined as having no lockup and requiring less-than-30-day redemption notice periods. 
Robustness tests suggest that (1) the negative link between failure probability and future hedge fund returns is robust to macroeconomic uncertainty beta,5) (2) the negative link is robust to several specifications of failure prediction model, (3) the negative link is robust to all of three investment styles (directional, semi-directional, or non-directional), and the negative link within directional funds appears to be relatively strong, (4) the negative link is found in both onshore and offshore funds, (5) the negative link is robust to a new sample excluding small hedge funds, ${ }^{6}$ ) and (6) the negative link is robust to two subsample periods (1997-2005 vs. 2006-2012).

The rest of the paper is organized as follows. Section $I I$ describes the sample construction, proposes fund-level variables included in a failure prediction model, and conducts a t-test on fund-level variables between failure and non-failure groups across two definitions of hedge fund failures. Section III models a fund's probability of failure using a dynamic logit regression and reports the regression results for the full sample. Section IV shows the out-of-sample predictability of the failure prediction model, documents a robust negative link between failure probability and future hedge fund returns, and shows that the negative effect of failure probability on future fund returns is sharply higher when hedge funds have weak share restrictions. Section V reports the results from several robustness tests. Section VI concludes.

5) Bali, et al. (2014) show a positive link between macroeconomic uncertainty beta (Macro-beta) and future hedge fund returns. Thus, one may be curious about whether Macro-beta explains the negative effect of failure probability on future hedge fund returns. Although I confirm a positive link between Macro-beta and future hedge fund returns, I find that failure probability and Macro-beta affect future fund returns independently.

6) Since failed funds are typically smaller in size than non-failed funds, I construct a subsample excluding the bottom $20 \%$ small funds by average fund size. The negative link between failure probability and future fund returns is robust to the subsample excluding extremely small hedge funds. 


\section{The Characteristics of Hedge Fund Failures}

\subsection{Sample Construction}

In this paper, I employ the TASS database7) that provides monthly returns, monthly assets under management (AUM), and several fund characteristics at the individual fund level. The sample period includes data from January 1994 to December 2012.

There are two major data biases documented in the hedge fund literature. First, a survivorship bias naturally occurs if a sample includes only live funds whereas the true population includes both live and defunct (so-called dead) funds. TASS maintains two separate databases: Live and Graveyard databases. Hedge funds in the Live database are considered to be live funds. Once a hedge fund stops reporting to the database, the fund is transferred into the Graveyard database and is considered to be a defunct fund. Since TASS created the Graveyard database in 1994, my sample period starts from January 1994 in order to be free of survivorship bias. Second, a backfill bias can occur because many hedge funds bring nice past fund performance in order to attract potential investors when they enter the database. To avoid backfill bias, I follow Fung and Hsieh (2000) and delete the first 12-month return histories of all funds. ${ }^{8}$ )

For further data screening, funds are dropped if they do not report net-of-fee (versus gross) returns, do not report monthly (versus quarterly) returns, or do not report returns and assets under management in U.S. dollars. I also require each fund to have at least 24-month consecutive return history during the sample period. In terms of style, I focus on individual hedge funds.9) Finally, I exclude funds that do not report their asset size (i.e., AUM) information. If a fund's AUM is

7) Liang (2000) shows that TASS provides more accurate data than the main alternative data source, HFR.

8) Although TASS records the date on which a hedge fund enters the database, Fung and Hsieh (2009) document that (1) not all the data prior to the entering date are "backfill-biased" and (2) a substantial loss of information occurs if we delete each fund's returns before its entry date.

9) I exclude funds-of-funds, managed futures, options, others, and undefined according to TASS's classification of 14 styles: convertible arbitrage, dedicated short bias, emerging markets, equity market neutral, event driven, fixed income arbitrage, global macro, long/short equity hedge, multi-strategy, fund-of-funds, managed futures, options, others, and undefined. 
missing in month $t$, I replace it by its most recent available AUM information until month $t$ - 1 . This does not create an econometric problem because information at time $t-1$ is still available at time $t$.

TASS assigns one of the following drop reasons to each defunct fund: (1) liquidated, (2) no longer reporting to TASS, (3) TASS has been unable to contact the manager for updated information, (4) closed to new investment, (5) merged into another entity, (6) dormant, and (7) unknown. Although it may seem reasonable to focus on liquidated funds for studying hedge fund failures, prior literature suggests that liquidation does not necessarily mean failure and part of the other defunct funds should be considered as failures (e.g., Liang and Park (2010)). Therefore, for robustness, I consider two different definitions of failures. The first definition of failure is liquidation. The second definition of failure follows Liang and Park (2010) where failure is defined as follows: (1) once listed in a database but stopped reporting, (2) negative average rate of return for the last 6 months, and (3) decreased AUM for the last 12 months.

\subsection{Variables Included in a Failure Prediction Model}

The main purpose of this paper is not to develop the best model for predicting hedge fund failures but to examine the relationship between a fund's estimated probability of failure and its future returns. Hence, I propose a relatively simple failure prediction model where the selection of variables included in the failure prediction model focuses on performance, fund flows, risk, and share restriction variables.

\section{Performance variables}

- $\operatorname{Ret}[\mathrm{t}-24, \mathrm{t}-1]$ : average of monthly net-of-fee returns from month $t-24$ to $t-1$

- $\mathrm{I}(\operatorname{Ret}[\mathrm{t}-24, \mathrm{t}-1]<0)$ : an indicator variable where the variable takes the value of 1 if the average return is negative over the period and 0 otherwise

- Ratio of negative ret[t-24, $\mathrm{t}-1]$ : proportion of negative monthly returns over the period 
Prior research documents that poor past performance is the main reason for hedge fund failures (e.g., Liang (2000), Brown et al. (2001), Baquero et al. (2005), and Grecu et al. (2007)). A fund's poor performance also makes it distant from the high water mark (HWM). Thus, the fund manager may take less effort to improve the fund's performance since he or she has little chance to receive the fund's performance fees. As a result, the fund may fail (Chakraborty and Ray (2010)).10)

\section{Fund-flow variables}

- Flow[t-24, $\mathrm{t}-1]$ : average of monthly fund flows from month $t-24$ to $t-1$ where monthly fund flows are defined as growth rates in asset under management minus monthly returns ${ }^{11)}$

- I(Flow $[t-24, t-1]<0)$ : an indicator variable where the variable takes the value of 1 if the average flow is negative over the period and 0 otherwise

- Ratio of negative flow[t-24, t-1]: proportion of negative monthly flows over the period

If investors pull out substantial amounts of their capital following poor fund performance, it may force the fund to liquidate its business. Fung, Hsieh, Naik and Ramadorai (2008) document that beta-only funds facing below-median capital inflows are more likely to be liquidated in subsequent two years.

\section{Risk variables}

- Volatility[t-24, t-1]: standard deviation of monthly returns from month $t-24$ to $t-1$

- Skewness[t-24, t-1]: skewness of monthly returns over the period

- Kurtosis[t-24, t-1]: kurtosis of monthly returns over the period

I choose three moments (volatility, skewness, and kurtosis) as risk variables

10) In unreported analysis, I also explored the distance-to-HWM variable (return-to-HWM) as defined in Chakraborty and Ray (2010). Consistent with their findings, the probability of hedge fund failure is higher as higher returns are required to hit the HWM. However, the marginal impact of the distance-to-HWM variable on failure probability is economically and statistically insignificant after controlling for past performance and past fund flows.

11) I measure the monthly fund flow of each fund by following Sirri and Tufano (1998). If a fund's AUM is missing in month $t$, I assume that there is no fund flow during the month. To mitigate the effect of outliers, I truncate the monthly fund flow variable at the 1 and 99 percentiles, $-33.7 \%$ and $40.1 \%$, respectively. 
because Bali, et al. (2012) investigates the significance of the three moments in predicting the cross-sectional variation in hedge fund returns. All other things being equal, a fund with higher risk (measured by higher volatility, negatively higher skewness, and higher kurtosis) has a higher chance of extremely low returns, which can be associated with a higher probability of failure.

\section{Share restriction variables}

- Redemption period: redemption notice period in days

- Dummy lockup12): an indicator variable where the variable takes the value of 1

if a fund has a lockup provision and 0 otherwise

Share restrictions provide hedge fund managers with more flexibility to engage in long-term arbitrage opportunities. If a fund does not have any share restriction, investors may withdraw capital immediately following poor performance, potentially leading to asset fire sales. In contrast, a longer share restriction period can attenuate the impact of such a threat, resulting in lower failure risk.

\section{Other fund-level variables}

- Size[t-1]: a fund's asset under management in millions at the end of month $t-1$

- Age[t]: the number of months since fund inception at month $t$

Fund size can also affect hedge fund failures. Some strategies have high fixed costs and are therefore not profitable on a small scale. Thus, larger funds may be more profitable and consequently have less failure risk.

A fund's age may be related to failure risk. Brown, et al. (2001) examine a linear relation and find that old funds have lower failure risk than young funds due to the fact that more mature funds take less risk and pursue more sustainable strategies. Baquero, et al. (2005) finds an evidence of a nonlinear relationship between fund age and failure risk. More specifically, they find that a fund's failure risk increases up to a certain age and subsequently starts to drop once it survives a certain threshold. To examine a nonlinear relation between a fund's age and its

12) Although a lockup period variable is continuous, I transform it to a binary variable (whether a fund has lockup provision or not) following Aragon (2007) who finds funds with lockup provision perform better than funds without lockup provision. 
probability of failure, I also include squared age to capture a potential nonlinear relation between them.

\section{Non-fund-level control variables}

- Dec $[\mathrm{t}]$ : an indicator variable where the variable takes 1 if December, 0 otherwise

- Strategy[j]: an indicator variable where the variable takes 1 if a fund's strategy belongs to $j{ }^{13)}$ by TASS, 0 otherwise

Hedge funds may drop out more frequently in their fiscal year-end month because the fund manager has an incentive to wait until the fund's fiscal year-end date in order to collect fees, and furthermore, hedge fund auditors are more likely to detect any of the fund's problems. Since most fiscal year-end months are found in December, ${ }^{14)}$ I use Dec[t] to control for the fiscal year-end effect on failure probability. As for any strategy effect on hedge fund failures, a set of indicator variables for trading strategy are included in the failure prediction model, where the benchmark style is "Long/Short Equity" strategy.

\subsection{Two Different Definitions of Hedge Fund Failure}

The first definition of hedge fund failure is liquidation. Panel A in Table 1 reports that the number of liquidated funds is 1,205 and the number of non-liquidated funds is 2,652 in the sample. I also consider another definition of hedge fund failure by Liang and Park (2010) (hereafter, LP-failure). According to the second definition of fund failure, the number of failed funds is 1,041 and the number of non-failed funds is 2,816 . Interestingly, the number of failed funds by both definitions is only 541. Therefore, $664\left(=1,205^{-541)}\right.$ liquidated funds are

13) Convertible Arbitrage, Dedicated Short Bias, Emerging Markets, Equity Market Neutral, Event Driven, Fixed Income Arbitrage, Global Macro, or Multi-Strategy

14) A more direct way to control for the fiscal year-end effect is to include a dummy variable for a fund's fiscal year-end month. Unfortunately, $10.6 \%$ of the sample does not have information about the fiscal year-end month. Within the remaining sample, $83.4 \%$ of the funds report that December is their fiscal year-end month. Thus, I use a December dummy variable to increase the sample size as well as to keep the fiscal year-end effect. 
classified as non-failed funds by LP-failure and 500 (=1,041-541) failed funds by LP-failure are not liquidated. Since one definition of fund failure does not include the other definition of fund failure, the use of both definitions of fund failure would be a good compromise for testing robustness. Hence, if this paper's main result about how a fund's failure probability affects its future returns is robust to the two definitions of fund failure, we can conclude that the main result is largely robust to the definition of fund failure.

\subsection{Fund Characteristics: Non-Failure Group vs. Failure Group}

Panel B of Table 1 reports the mean value of each fund-level variable across non-failure and failure fund-month groups. Note that the non-failure months of a failed fund are treated as non-failure observations. This is because only the failure-month observation of a failed fund is treated as a failure event in modeling the probability of fund failure.

Panel B also shows there are significant differences in fund-level variables between failure group and non-failure group. To test the difference in the two groups, I implement the unpaired two-sample t-test by Satterthwaite (1946) because this methodology is more suitable when the variances of the two groups are different. The test results suggest that the failure event of the typical hedge fund is associated with poor past performance, fund outflows, higher risk-taking, smaller fund size, and weak share restrictions. 


\section{$11 \quad$ BOK Working Paper No.2015-13(2015.4)}

\section{Table 1: Number of Funds and Difference in Fund Characteristics by Fund Failure}

Panel A: Number of funds

\begin{tabular}{lrrr} 
& Liquidation $=$ Yes & Liquidation $=$ No & Total \\
LP_failure $=$ Yes & 541 & 500 & 1,041 \\
LP_failure $=$ No & 664 & 2,152 & 2,816 \\
\hline Total & 1,205 & 2,652 & 3,857 \\
\hline
\end{tabular}

Panel B: Difference in fund-level variables across Non-failure vs Failure groups

\begin{tabular}{|c|c|c|c|c|c|c|}
\hline \multirow[b]{2}{*}{ Variable } & \multicolumn{3}{|c|}{ Panel B-1: Failure = Liquidation } & \multicolumn{3}{|c|}{ Panel B-2: Failure = LP_failure } \\
\hline & $\begin{array}{c}(1) \\
\text { Non-failure }\end{array}$ & $\begin{array}{c}(2) \\
\text { Failure }\end{array}$ & $\begin{array}{l}\text { Diff: } \\
(2)-(1)\end{array}$ & $\begin{array}{c}(1) \\
\text { Non-failure }\end{array}$ & $\begin{array}{c}(2) \\
\text { Failure }\end{array}$ & $\begin{array}{l}\text { Diff: } \\
(2)-(1)\end{array}$ \\
\hline $\operatorname{Ret}[t-24, t-1]$ (\% per month) & 0.85 & -0.05 & $-0.90^{* * *}$ & 0.86 & -0.31 & $-1.16^{* * *}$ \\
\hline $\mid(\operatorname{Ret}[t-24, t-1]<0)$ & 0.17 & 0.46 & $0.29^{* * *}$ & 0.17 & 0.60 & $0.43^{* * *}$ \\
\hline Ratio of negative ret[t-24,t-1] & 33.97 & 44.23 & $10.25^{* * *}$ & 33.97 & 48.07 & $14.10^{* * *}$ \\
\hline Flow[t-24,t-1] (\% per month) & 0.61 & -1.52 & $-2.13^{* * *}$ & 0.61 & -1.63 & $-2.24^{* * *}$ \\
\hline I(Flow $[t-24, t-1]<0)$ & 0.44 & 0.75 & $0.30^{* * *}$ & 0.44 & 0.77 & $0.32^{* * *}$ \\
\hline Ratio of negative flow $[t-24, t-1]$ & 34.88 & 47.12 & $12.24^{* * *}$ & 34.87 & 50.40 & $15.53^{* * *}$ \\
\hline Size[t-1] (millions) & 194.09 & 62.09 & $-132.00^{* * *}$ & 193.86 & 95.14 & $-98.72^{* * *}$ \\
\hline Volatility $[t-24, t-1]$ (\% per month) & 3.83 & 3.72 & -0.11 & 3.82 & 4.48 & $0.66^{* * *}$ \\
\hline Skewness $[t-24, t-1]$ & -0.32 & -0.79 & $-0.47^{* * *}$ & -0.32 & -1.20 & $-0.88^{* * *}$ \\
\hline Kurtosis $[t-24, t-1]$ & 0.94 & 2.07 & $1.13^{* * *}$ & 0.94 & 3.04 & $2.10^{* * *}$ \\
\hline Age[t] (months) & 79.13 & 82.82 & $3.69^{* * *}$ & 79.11 & 86.30 & $7.19^{* * *}$ \\
\hline Redemption period (days) & 39.51 & 33.82 & $-5.69^{* * *}$ & 39.50 & 37.02 & $-2.48^{* * *}$ \\
\hline Dummy lockup (0/1) & 0.33 & 0.24 & $-0.09^{* * *}$ & 0.33 & 0.32 & -0.01 \\
\hline Observations & 258,487 & 1,205 & & 258,651 & 1,041 & \\
\hline
\end{tabular}

Notes: This table reports number of funds and difference in fund characteristics by fund failure. Panel A reports number of failed and non-failed funds across two different definitions of fund failure. The first definition is "liquidation". The second definition is failure defined by Liang and Park (2010) (hereafter, "LP_failure"). Panel B reports fund-level variables' mean values across non-failure and failure fund-month groups, and tests whether each variable's mean values are equal between the two groups based on the assumption that the variances of the two groups are unequal. Even for a failed fund, non-failure months are treated as non-failure fund-month observations. A brief description of variables is as follows: Ret[t-24, $t-1]$ (average of monthly net-of-fee returns from month $t-24$ to $t-1), \quad I(\operatorname{Ret}[t-24, t-1]<0)$ (indicator where the variable takes the value of 1 if the average return is negative, 0 otherwise), Ratio of negative ret[t-24,t-1] (proportion of negative monthly returns over the period), Flow[t-24, t-1] (average of monthly fund flows), I(Flow[t-24,t-1]<0) (indicator where the variable takes the value of 1 if the average flow is negative, 0 otherwise), Ratio of negative flow[t-24,t-1] (proportion of negative monthly flows), Size[t-1] (a fund's assets under management in month t-1), Volatility[t-24, t-1] (standard deviation of monthly returns), Skewness[t-24, t-1] (skewness of monthly returns), Kurtosis[t-24, t-1] (kurtosis of monthly returns), Age[t] (the number of months since fund inception in month $t$ ), Redemption Period (in days), and Dummy lockup (1 if a fund uses lockup restriction, 0 otherwise). The sample period is January 1994 to December 2012. 


\section{Modeling a Probability of Hedge Fund Failure}

\subsection{Model Specification}

In Section II.2, I propose several fund-level variables to be included in a failure prediction model. In this section, I explain the dynamic logit model and why it is preferable to alternative failure prediction models.

Shumway (2001) supports the use of hazard models for forecasting corporate bankruptcies. He states that single-period static models produce biased and inconsistent estimates by ignoring the fact that firms change over time. The same argument also applies for modeling hedge fund failures. Moreover, Shumway (2001) shows that the hazard models can be easily estimated using a maximum likelihood estimation based on a logit estimation program. ${ }^{15)}$

The hedge fund literature also uses the semi-parametric proportional hazard rate model by Cox (1972) to predict hedge fund failures (e.g., Brown, et al. (2001), Grecu, et al. (2007), Liang and Park (2010)). In this paper, however, I need to estimate a calendar-time probability of failure for each hedge fund to examine a directional link between failure probability and future hedge fund returns. For this task, the dynamic logit model is preferable to the Cox model because the Cox model is an event-time analysis based on each fund's lifetime duration data. ${ }^{16)}$

Since I model the failure probability of hedge funds using a dynamic logit regression, the failure probability is mathematically specified as follows:

$$
\operatorname{Pr}\left(y_{i, t}=1\right)=\exp \left(\sum_{j=1}^{M} x_{i, j, t-1} \beta_{j}\right) /\left\{1+\exp \left(\sum_{j=1}^{M} x_{i, j, t-1} \beta_{j}\right)\right\}
$$

where $y_{i, t}$ is an indicator that takes on the value of 1 if a fund $i$ fails in month $t, x_{i, j, t-1}$ is the value of the variable $j$ of fund $i$ in month $t-1$, and $\beta_{j}$ measures how a variable $j$ affects failure probability. In terms of the interpretation of estimated parameter values, a positive (negative) $\beta_{j}$ implies that the variable $j$ increases (decreases) failure probability.

15) Shumway (2001) shows that a multi-period (dynamic) logit model is equivalent to a discrete-time hazard model.

16) A directional effect of any fund-level variable on failure probability should be robust to the choice of a failure prediction model between a parametric dynamic logit regression and a semi-parametric Cox proportional hazard rate model because both models essentially rely on the same likelihood function. 


\subsection{Regression Results}

In Table 2, I examine how fund-level variables affect failure probability. In Panel A, failure means liquidation. In Panel B, failure is defined by LP-failure. I report both statistical and economic significance for each regression. For the statistical significance, I compute t-values using the standard errors clustered by hedge funds. For the economic significance, the marginal effect of each variable is computed as the change in failure probability expressed in percent when a continuous variable increases by one standard deviation at its mean value or a binary variable moves from zero to one, ceteris paribus.

The following interpretation is based on the results reported in Panel A (where failure means liquidation). The marginal effect of each covariate is based on the benchmark failure probability, $0.50 \%(=1,156 / 230,859)$ per month. First, poor performance increases a probability of hedge fund failure. All other things being equal, a one standard deviation decrease of $\operatorname{Ret}[\mathrm{t}-24, \mathrm{t}-1]$ increases the failure probability from $0.50 \%$ to $0.64 \%$ by 0.14 percentage points (pp) per month. If a fund's average return over the past two years is negative (i.e., I(Ret[t-24, $\mathrm{t}-1]<0)=1$ ), it increases the failure probability by $0.06 \mathrm{pp}$. Furthermore, a one standard deviation increase in the ratio of negative returns over the same period increases the failure probability by $0.13 \mathrm{pp}$. Second, fund withdrawals by investors increase the failure probability. A one standard deviation decrease of Flow[t-24, t-1] increases the failure probability by $0.17 \mathrm{pp}$. If a fund experiences outflows over the past two years (i.e., I(Flow $[\mathrm{t}-24, \mathrm{t}-1]<0)=1$ ), it increases the failure probability by $0.07 \mathrm{pp}$. Third, the smaller the hedge fund is, the more likely it is to fail, ceteris paribus. The failure probability increases by $0.20 \mathrm{pp}$ if a fund's size decreases by one standard deviation. Fourth, I find an inverse U-shaped relation between fund age and failure risk. Failure risk increases with a fund's age up to a threshold (about 6.5 years $^{17)}$ passed since the inception date of the fund) and then declines. The nonlinear relationship is consistent with the finding of Baquero et al. (2005) in the hedge fund literature and that of Lunde, Timmermann and Blake (1999) in the mutual fund literature.

17) The failure probability of a fund is maximized when the fund's age is in 78 months (=exp[7.23/(-2×(-0.83))]). 
Table 2: Modeling a Probability of Hedge Fund Failure: Logit Regressions

\begin{tabular}{|c|c|c|c|c|c|c|c|}
\hline & \multirow[b]{2}{*}{$\begin{array}{l}\text { Expected } \\
\text { Sign }\end{array}$} & \multicolumn{3}{|c|}{ Panel A: Failure = Liquidation } & \multicolumn{3}{|c|}{ Panel B: Failure = LP_Failure } \\
\hline & & $\begin{array}{l}\text { Parameter } \\
\text { Estimate }\end{array}$ & t-value & $\begin{array}{c}\text { Marginal } \\
\text { Effect }\end{array}$ & $\begin{array}{l}\text { Parameter } \\
\text { Estimate }\end{array}$ & t-value & $\begin{array}{c}\text { Marginal } \\
\text { Effect }\end{array}$ \\
\hline $\operatorname{Ret}[t-24, t-1]$ & $(-)$ & -21.66 & -5.33 & $-0.14 \%$ & -6.16 & -1.75 & $-0.04 \%$ \\
\hline $\mid(\operatorname{Ret}[t-24, t-1]<0)$ & $(+)$ & 0.31 & 3.19 & $0.06 \%$ & 0.65 & 6.10 & $0.11 \%$ \\
\hline $\begin{array}{l}\text { Ratio of negative } \\
\text { ret }[t-24, t-1]\end{array}$ & $(+)$ & 1.67 & 5.22 & $0.13 \%$ & 3.26 & 9.46 & $0.23 \%$ \\
\hline Flow $[t-24, t-1]$ & $(-)$ & -11.37 & -6.73 & $-0.17 \%$ & -9.66 & -5.52 & $-0.13 \%$ \\
\hline $\mid($ Flow $[t-24, t-1]<0)$ & $(+)$ & 0.29 & 3.14 & $0.07 \%$ & 0.31 & 3.11 & $0.07 \%$ \\
\hline Ratio of negative flow $[\mathrm{t}-24, \mathrm{t}-1]$ & $(+)$ & -0.03 & -0.18 & $0.00 \%$ & 0.28 & 1.46 & $0.03 \%$ \\
\hline Size $[t-1]$ & $(-)$ & -0.23 & -8.92 & $-0.20 \%$ & -0.20 & -9.42 & $-0.16 \%$ \\
\hline Volatility $[t-24, t-1]$ & $(+)$ & -11.95 & -7.54 & $-0.20 \%$ & -3.61 & -2.65 & $-0.05 \%$ \\
\hline Skewness $[t-24, t-1]$ & $(-)$ & -0.05 & -1.61 & $-0.03 \%$ & -0.21 & -5.09 & $-0.12 \%$ \\
\hline Kurtosis $[t-24, t-1]$ & $(+)$ & 0.02 & 1.91 & $0.03 \%$ & -0.01 & -0.61 & $-0.01 \%$ \\
\hline Age[t] & $(+)$ & 7.23 & 8.31 & $2.04 \%$ & 6.39 & 7.07 & $1.62 \%$ \\
\hline Age $[\mathrm{t}]^{\wedge} 2$ & $(-)$ & -0.83 & -8.04 & $-1.99 \%$ & -0.71 & -6.71 & $-1.54 \%$ \\
\hline Redemption period & $(-)$ & 0.00 & -1.60 & $-0.03 \%$ & 0.00 & 1.68 & $0.03 \%$ \\
\hline Dummy lockup & $(-)$ & -0.30 & -4.10 & $-0.15 \%$ & 0.06 & 0.77 & $0.03 \%$ \\
\hline December & $(+)$ & 0.78 & 9.64 & $0.39 \%$ & 0.45 & 4.82 & $0.20 \%$ \\
\hline Convertible Arbitrage & & 0.08 & 0.58 & $0.04 \%$ & 0.33 & 2.08 & $0.15 \%$ \\
\hline Dedicated Short Bias & & 0.20 & 1.23 & $0.10 \%$ & -0.04 & -0.16 & $-0.02 \%$ \\
\hline Emerging Markets & & -0.05 & -0.45 & $-0.02 \%$ & -0.27 & -2.29 & $-0.12 \%$ \\
\hline Equity Market Neutral & & 0.17 & 1.49 & $0.09 \%$ & 0.36 & 2.87 & $0.16 \%$ \\
\hline Event Driven & & -0.19 & -1.71 & $-0.10 \%$ & -0.06 & -0.46 & $-0.03 \%$ \\
\hline Fixed Income Arbitrage & & -0.16 & -0.93 & $-0.08 \%$ & 0.42 & 2.40 & $0.19 \%$ \\
\hline Global Macro & & 0.11 & 0.89 & $0.05 \%$ & 0.31 & 2.57 & $0.14 \%$ \\
\hline Multi-Strategy & & 0.15 & 1.24 & $0.07 \%$ & 0.30 & 2.48 & $0.14 \%$ \\
\hline McFadden's R-square & & & & $10.83 \%$ & & & $13.14 \%$ \\
\hline \# of Failure Funds & & & & 1,156 & & & 1,041 \\
\hline \# of Observations & & & & 230,859 & & & 230,859 \\
\hline
\end{tabular}

Notes: This table reports results from modeling a probability of hedge fund failure based on dynamic logit regressions. If a fund fails in month $t$, the fund's failure indicator is 1 in month $t$ and 0 in other months. In Panel A, failure is defined as liquidation. In panel B, failure is LP_failure. A positive (negative) parameter estimate for a variable suggests that the variable increases (decreases) the probability of fund failure. I report t-values using the standard errors clustered by fund. The marginal effect of each variable represents the change in failure probability expressed in percents as a continuous variable increases by one standard deviation at its mean value or a binary variable changes from zero to one, ceteris paribus. December is a dummy variable which is one if an observationís calendar month is December and zero otherwise. A set of dummy variables for trading strategy styles is included to control for any style effect on fund failures, where the benchmark style is "Long/Short Equity" strategy. Size and Age variables are included in logit regressions after taking a log transformation. The pseudo-R2 of McFadden (1974) for each regression model is computed as 1-L1/L0 where L1 is the log likelihood of the model and L0 is the log likelihood of a null model with only a constant term. The sample period is January 1994 to December 2012. 


\section{Failure Probability and Hedge Fund Performance}

\subsection{Hedge Fund Portfolios Grouped by Predicted Probability of Failure}

In this section, I examine how the predicted failure probability of hedge funds is related to their future performance. In order to obtain a measure of the predicted failure probability, I estimate the failure prediction model every month using a rolling-window approach based on only prior information, instead of using the parameter estimates obtained from the full-sample results. I highlight that the predicted failure probability is the ex ante measure because (1) the ex ante measure avoids any potential look-ahead bias, (2) it allows me to examine an out-of-sample prediction analysis, and (3) it allows me to implement a trading strategy.

The variables included in the failure prediction model are the same as in Table 2. Specifically, at the end of each month $t$-1 since December 1996, the failure prediction model is estimated using the previous three-year observations. At the beginning of month $t$ starting from January 1997, I estimate the failure probability of a hedge fund by combining each variable's parameter value estimated in month $t-1$ from the model with each variable's observation value for the fund in month $t-1$ :

$$
\begin{aligned}
& \text { Failure Probability }_{i, t} \\
& \qquad=\exp \left(\sum_{j=1}^{M} x_{i, j, t-1} \hat{\beta}_{j, t-1}\right) /\left\{1+\exp \left(\sum_{j=1}^{M} x_{i, j, t-1} \hat{\beta}_{j, t-1}\right)\right\}
\end{aligned}
$$

$x_{i, j, t-1}$ is the value of the variable $j$ of fund $i$ observed in month $t-1$ and $\hat{\beta}_{j, t-1}$ is the parameter value of the variable $j$ estimated in month $t$ - 1 . It is important to note that the predicted probability of failure relies on only prior information. At the beginning of each month starting from January 1997, I sort individual hedge funds into quintile groups by the predicted probability of failure.

Since I group hedge funds into quintiles based on the predicted failure probability, I can examine the out-of-sample predictability of the failure prediction model. If the model can classify hedge funds well out-of-sample, a quintile group with higher failure probability will include more failed funds than a quintile group 
with lower failure probability. Panel A in Table 3 reports the out-of-sample predictability. Overall, the failure prediction model has reasonably good out-of-sample performance and the number of failed funds in each quintile monotonically increases with failure probability. In Panel A-1 where failure means liquidation, 711 failed funds (62.4\% out of 1,140 failed funds) are predicted from a quintile group with the highest failure probability, but only 35 failed funds (3.1\%) are predicted from a quintile group with the lowest failure probability. Similarly, when failure means LP-failure (Panel A-2), 701 failed funds (67.8\% out of 1,034 failed funds) are predicted from the highest failure risk quintile group, but only 21 failed funds (2.0\%) are predicted from the lowest failure risk quintile group.

Panel B reports a $5 \times 5$ transition matrix that provides summary statistics for the persistence of the probability of fund failure. Each cell (e.g., cell $(i, j))$ in the transition matrix represents the average probability that a fund in quintile $i$ in month $t$ moves to the quintile $j$ in month $t+1$. If the failure probability does not have any predictive power, then all the transition probabilities should be approximately $20 \%$. But results show that the average probability of staying in the same quintile group is higher than 75 78\% (depending on the definition of failure). In particular, the average probability of staying in the highest failure risk group is higher than $90 \%$. Therefore, a fund's probability of failure is a strong predictor for its probability of failure in the following month.

Table 4 reports the average hedge fund characteristics across the quintile groups. Overall, the quintile group with the highest failure probability has the worst past performance, faces the largest capital outflows, has the smallest fund size, takes the highest risks, and has the weakest share restrictions. Although the average fund characteristics across quintile groups are largely robust to the definition of fund failure, the highest failure risk group based on LP_failure (Panel B) has the highest volatility while the same group based on liquidation (Panel A) does not. 
Table 3: Out-of-Sample Predictability and a Transition Matrix of Failure Probability

Panel A: Out-of-sample predictability - Number of failed funds across quintiles by predicted failure probability

\begin{tabular}{|c|c|c|c|c|c|c|c|c|c|c|c|c|c|}
\hline \multirow[b]{2}{*}{ Year } & \multirow{2}{*}{$\begin{array}{l}\text { \# of Funds } \\
\text { per month in } \\
\text { each quintile }\end{array}$} & \multicolumn{6}{|c|}{ Panel A-1: Failure = Liquidation } & \multicolumn{6}{|c|}{ Panel A-2: Failure = LP_failure } \\
\hline & & Low & quin2 & quin3 & quin4 & High & $\begin{array}{r}\text { \# of } \\
\text { LP_failure }\end{array}$ & Low & quin2 & quin3 & quin4 & High & $\begin{array}{r}\text { \# of } \\
\text { LP_failure }\end{array}$ \\
\hline 1997 & 91 & 0 & 0 & 0 & 3 & 10 & 13 & 0 & 0 & 0 & 0 & 4 & 4 \\
\hline 1998 & 117 & 1 & 0 & 0 & 0 & 20 & 21 & 0 & 0 & 0 & 0 & 13 & 13 \\
\hline 1999 & 150 & 0 & 3 & 0 & 4 & 20 & 27 & 0 & 1 & 1 & 3 & 20 & 25 \\
\hline 2000 & 174 & 0 & 2 & 6 & 5 & 22 & 35 & 0 & 3 & 2 & 3 & 30 & 38 \\
\hline 2001 & 197 & 1 & 1 & 5 & 2 & 21 & 30 & 1 & 2 & 0 & 13 & 31 & 47 \\
\hline 2002 & 223 & 3 & 1 & 6 & 8 & 30 & 48 & 0 & 1 & 6 & 14 & 27 & 48 \\
\hline 2003 & 246 & 0 & 2 & 6 & 11 & 35 & 54 & 0 & 0 & 3 & 3 & 25 & 31 \\
\hline 2004 & 275 & 0 & 3 & 10 & 18 & 53 & 84 & 3 & 0 & 2 & 10 & 42 & 57 \\
\hline 2005 & 295 & 4 & 4 & 4 & 20 & 54 & 86 & 1 & 0 & 1 & 9 & 42 & 53 \\
\hline 2006 & 303 & 0 & 7 & 7 & 14 & 52 & 80 & 0 & 0 & 2 & 9 & 31 & 42 \\
\hline 2007 & 315 & 2 & 3 & 5 & 9 & 34 & 53 & 0 & 1 & 1 & 5 & 64 & 71 \\
\hline 2008 & 307 & 9 & 9 & 20 & 27 & 95 & 160 & 6 & 13 & 22 & 52 & 127 & 220 \\
\hline 2009 & 288 & 9 & 13 & 7 & 20 & 53 & 102 & 2 & 6 & 16 & 20 & 46 & 90 \\
\hline 2010 & 284 & 1 & 5 & 9 & 22 & 78 & 115 & 2 & 3 & 7 & 16 & 66 & 94 \\
\hline 2011 & 253 & 2 & 9 & 13 & 27 & 64 & 115 & 4 & 9 & 10 & 18 & 56 & 97 \\
\hline 2012 & 215 & 3 & 9 & 11 & 24 & 70 & 117 & 2 & 7 & 5 & 13 & 77 & 104 \\
\hline Total & & 35 & 71 & 109 & 214 & 711 & 1,140 & 21 & 46 & 78 & 188 & 701 & 1,034 \\
\hline
\end{tabular}

Panel B: A $5 \times 5$ Transition Matrix of the Probability of Fund Failure

\begin{tabular}{|c|c|c|c|c|c|c|c|c|c|c|}
\hline \multirow{3}{*}{$\begin{array}{c}\text { Probability } \\
\text { of failure in } \\
\text { month } t\end{array}$} & \multicolumn{5}{|c|}{ Panel B-1: Failure = Liquidation } & \multicolumn{5}{|c|}{ Panel B-2: Failure = LP_Failure } \\
\hline & \multicolumn{5}{|c|}{ Probability of failure in month $t+1$} & \multicolumn{5}{|c|}{ Probability of failure in month $t+1$} \\
\hline & Low & 2 & 3 & 4 & High & Low & 2 & 3 & 4 & High \\
\hline Low & $90.81 \%$ & $8.96 \%$ & $0.19 \%$ & $0.04 \%$ & $0.01 \%$ & $89.96 \%$ & $9.61 \%$ & $0.35 \%$ & $0.06 \%$ & $0.02 \%$ \\
\hline 2 & $6.62 \%$ & $80.92 \%$ & $11.87 \%$ & $0.55 \%$ & $0.04 \%$ & $7.34 \%$ & $78.66 \%$ & $13.29 \%$ & $0.66 \%$ & $0.05 \%$ \\
\hline 3 & $0.08 \%$ & $9.02 \%$ & $78.02 \%$ & $12.56 \%$ & $0.31 \%$ & $0.21 \%$ & $10.47 \%$ & $75.09 \%$ & $13.78 \%$ & $0.45 \%$ \\
\hline 4 & $0.02 \%$ & $0.29 \%$ & $9.69 \%$ & $80.16 \%$ & $9.84 \%$ & $0.03 \%$ & $0.44 \%$ & $11.02 \%$ & $77.57 \%$ & $10.93 \%$ \\
\hline High & $0.01 \%$ & $0.02 \%$ & $0.18 \%$ & $7.38 \%$ & $92.41 \%$ & $0.01 \%$ & $0.02 \%$ & $0.21 \%$ & $8.69 \%$ & $91.06 \%$ \\
\hline
\end{tabular}

Notes: This table examines the out-of-sample predictability of failure prediction models in Panel A. At the beginning of each month, I estimate the failure prediction model using prior three-year information. Using parameter coefficients from the estimation of the model, I measure a probability of failure for individual hedge funds and sort all individual funds into quintiles by the predicted probability of fund failure. Then, I examine the number of failed funds during the month for each quintile. This procedure is repeated every month from January 1997 to December 2012. I consider two definitions of failure: liquidation and LP_failure. In Panel B, I estimate a $5 \times 5$ transition matrix of the probability of fund failure. Each cell in the transition matrix represents the average probability that a fund in quintile $i$ in month $t$ will be in quintile $j$ in month $t+1$. 


\section{Table 4: Average Characteristics across Quintile Portfolios by Predicted Failure Probability}

\begin{tabular}{|c|c|c|c|c|c|c|c|c|c|c|}
\hline \multirow[b]{2}{*}{ Variables } & \multicolumn{5}{|c|}{ Panel A: Failure = Liquidation } & \multicolumn{5}{|c|}{ Panel B: Failure = LP_failure } \\
\hline & Low & quin2 & quin3 & quin4 & High & Low & quin2 & quin3 & quin4 & High \\
\hline Ret[t-24, t-1] (\% per month) & 1.65 & 1.08 & 0.86 & 0.52 & 0.03 & 1.56 & 1.14 & 0.93 & 0.56 & -0.04 \\
\hline $\mid(\operatorname{Ret}[t-24, t-1]<0)$ & 0.04 & 0.09 & 0.13 & 0.22 & 0.42 & 0.03 & 0.06 & 0.11 & 0.22 & 0.49 \\
\hline Ratio of neg. ret[t-24,t-1] (\%) & 26.41 & 30.98 & 33.73 & 37.44 & 43.33 & 23.58 & 29.78 & 34.11 & 38.63 & 45.79 \\
\hline How $[t-24, t-1]$ (\% per month) & 3.01 & 1.46 & 0.68 & -0.24 & -1.53 & 2.93 & 1.53 & 0.61 & -0.29 & -1.40 \\
\hline $\mid($ Flow $[t-24, t-1]<0)$ & 0.16 & 0.29 & 0.41 & 0.59 & 0.78 & 0.18 & 0.30 & 0.42 & 0.59 & 0.75 \\
\hline Ratio of neg. flow [t-24,t-1] (\%) & 28.85 & 35.39 & 39.43 & 43.93 & 49.41 & 29.15 & 34.65 & 39.09 & 44.04 & 50.08 \\
\hline Size[t-1] (millions) & 464.57 & 222.61 & 151.88 & 83.91 & 44.48 & 404.76 & 224.96 & 168.24 & 106.82 & 62.56 \\
\hline Volatility[t-24, t-1](\% per month) & 4.24 & 3.87 & 3.77 & 3.80 & 3.80 & 3.68 & 3.62 & 3.83 & 4.04 & 4.31 \\
\hline Skewness $[t-24, t-1]$ & -0.07 & -0.27 & -0.33 & -0.43 & -0.73 & 0.07 & -0.21 & -0.31 & -0.49 & -0.89 \\
\hline Kurtosis $[t-24, t-1]$ & 0.48 & 0.75 & 0.91 & 1.21 & 1.99 & 0.67 & 0.65 & 0.78 & 1.15 & 2.08 \\
\hline Redemption period (days) & 53.80 & 44.42 & 39.64 & 35.60 & 28.57 & 50.30 & 42.62 & 39.24 & 37.20 & 32.69 \\
\hline Dummy lockup (0/1) & 0.57 & 0.43 & 0.31 & 0.26 & 0.17 & 0.44 & 0.40 & 0.34 & 0.29 & 0.25 \\
\hline Failure Probability (\% per month) & 0.06 & 0.14 & 0.25 & 0.46 & 1.54 & 0.04 & 0.11 & 0.22 & 0.44 & 1.76 \\
\hline
\end{tabular}

Notes: This table reports the average value of several variables across quintile portfolios grouped by the predicted probability of fund failure. Fund-month observations are used to compute the average of each variable in a quintile portfolio. In Table 3, I explain how individual funds are grouped into quintiles. Variables (except for Failure Probability) are defined in Table 1. Two definitions of hedge fund failure are considered: liquidation (Panel A) and LP_failure (Panel B).

\subsection{Failure Probability and Hedge Fund Performance: Time-series Regression}

After sorting individual hedge funds into quintiles by the predicted failure probability at the beginning of each month, I compute the equally-weighted ${ }^{18}$ ) return for each quintile portfolio during the month. As a result, I obtain a series of monthly returns of each quintile portfolio from January 1997 to December 2012.

To do a time-series performance test, I need an asset pricing model to adjust for common risk factors. ${ }^{19)}$ The seven-factor model of Fung and Hsieh (2004) is often

18) I also compute value-weighted returns (using a fund's size in month $t-1$ as a weight) and find similar results. For simplicity, I do not report the results based on value-weighted returns.

19) The well-known three factors by Fama and French (1993) are not sufficient for hedge funds because hedge funds hold broader asset classes than mutual funds and also create nonlinear payoffs by using high leverage, derivatives, and short sales. Agarwal and Naik (2004) show that hedge fund returns have option-like properties due to their trading strategies. 
used for evaluating hedge fund performance in the hedge fund literature (e.g., Kosowski, Naik and Teo (2007) and Fung et al. (2008)). Their seven factors include three primitive trend-following (or look-back straddle) factors on bonds (PTFBD), currencies (PTFFX), and commodities (PTFCOM).20) The other four factors are excess market returns (CRSP value-weighted returns minus 1-month T-bill rates) (MKTRF), size factor (small cap minus big cap) (SMB), ${ }^{21)}$ change in credit spreads (Moody's Baa yield minus 10-year treasury yield) $(\triangle \mathrm{DEF})$, and change in 10-year treasury yields $(\Delta \mathrm{Y} 10) .22)$

In addition to the seven factors by Fung and Hsieh (2004), I consider two more factors, book-to-market factor (HML) and Carhart (1997)'s momentum factor (UMD).23) Finally, I include excess market returns with 1- and 2-month lags to control for a smoothing effect of reported returns. ${ }^{24)}$ Therefore, I estimate the following time-series asset-pricing model ${ }^{25)}$ for each quintile portfolio:

$$
\begin{aligned}
& r_{i, t}=a_{i}+\beta_{1(0) i} M K T R F_{t}+\beta_{1(1) i} M K T R F_{t-1}+\beta_{1(2) i} M K T R F_{t-2}+\beta_{2 i} S M B_{t} \\
& +\beta_{3 i} H M L_{t}+\beta_{4 i} U M D_{t}+\beta_{5 i}(\triangle D E F)_{t}+\beta_{6 i}(\triangle Y 10)_{t}+\beta_{7 i} P T F B D_{t} \\
& +\beta_{8 i} \text { PTFFX } X_{t}+\beta_{9 i} \text { PTFCOM }_{t}+\varepsilon_{i, t}
\end{aligned}
$$

20) Fung and Hsieh (2001) explain the construction of trend-following factors in detail. Also, trend following factors are available at http://faculty.fuqua.duke.edu/ dah7/DataLibrary/TF-FAC.xls.

21) Fung and Hsieh (2004) originally use S\&P 500 index returns and Wilshire small cap minus large cap returns instead of CRSP value-weighted returns and Fama-French's SMB factor, respectively.

22) I obtain Moody's Baa yields and 10-year treasury yields from H.15 reports of Federal Reserve statistical release.

23) The Fama-French's three factors and Carhart's momentum factor are taken from Prof. French's website.

24) Asness, Krail and Liew (2001) find the market exposure of hedge fund returns is underestimated in a regression using only contemporaneous market returns because many hedge funds hold illiquid or hard-to-price assets that often create non-synchronous returns. They show hedge funds' betas increase after including lagged market returns in the regression. Similarly, Getmansky, Lo and Makarov (2004) and Getmansky, Lo and Mei (2004) model the monthly reported (observable) returns of hedge funds as an $\mathrm{MA}(2)$ process of true (unobservable) returns. If true returns move with observable market factors, the smoothing effect of reported returns can be mitigated by including lagged market returns in a time-series regression.

25) The addition of liquidity risk factor to the regression model does not have any material impact on the results reported in this paper. Liquidity risk factor is defined as the return spread between hedge funds with high liquidity risk and hedge funds with low liquidity risk (see Sadka (2010)). I thank Ronnie Sadka for providing me with his liquidity risk factor returns for hedge funds. 
where $r_{i, t}$ is the excess returns of quintile portfolio $i$ in month $t$, and $\alpha_{i}$ measures the average risk-adjusted excess return of quintile portfolio $i$.

Table 5 reports the results from the time-series asset pricing model for explaining returns on quintile portfolios and the zero-cost spread portfolio (long position in a quintile group with the lowest failure probability and short position in a quintile with the highest failure probability). It is important to note that the last two monthly returns of failed funds are removed before evaluating the performance of quintile portfolios and the spread portfolio. Since the last two monthly returns of failed funds often include the most negative performance, the results after removing the potentially worst performance could be viewed as conservative. Thus, if a negative relationship between the probability of failure and future performance is discovered after removing the last two monthly returns of failed funds, the actual relationship between the failure probability and future performance should be more negative than reported in this paper.

In Panel A where failure means liquidation, I find that a fund's failure probability predicts negatively the fund's future returns. The average return on the quintile portfolio with the lowest failure risk is $0.88 \%$ per month, while the average monthly return on the portfolio with the highest failure risk is $0.36 \%$. Thus, the return spread between the two portfolios is $0.52 \%$ per month $(\mathrm{t}-\mathrm{stat}=5.14)$. Furthermore, the alpha (risk-adjusted return) spread between the two portfolios is $0.49 \%$ per month $(\mathrm{t}$-stat $=5.50)$, suggesting that exposures to a large number of risk factors do not much explain the return spread between the two portfolios by the difference in failure risk. Similarly, in Panel B where failure is defined by LP-failure, the return and alpha spread between the two extreme quintile portfolios are $0.44 \%$ per month $(\mathrm{t}$-stat $=3.29)$ and $0.41 \%$ per month $(\mathrm{t}$-stat $=3.98)$, respectively. Therefore, the significantly negative relationship between the probability of failure and future performance is robust to the definition of fund failure. 
Table 5: Time-Series Regressions for Quintile Portfolios by Predicted Failure Probability

\begin{tabular}{|c|c|c|c|c|c|c|c|c|c|c|c|c|c|c|}
\hline $\begin{array}{l}\text { Failure } \\
\text { Risk }\end{array}$ & $\begin{array}{l}\text { Raw } \\
\text { Return }\end{array}$ & Alpha & MKTRF & LAG1 & LAG2 & SMB & HML & UMD & $\triangle \mathrm{DEF}$ & $\Delta Y 10$ & PTFBD & PTFFX & PTFCOM & AdjR2 \\
\hline Low & $\begin{array}{c}0.88 \\
(5.37)\end{array}$ & $\begin{array}{c}0.46 \\
(4.50)\end{array}$ & $\begin{array}{c}0.30 \\
(12.33)\end{array}$ & $\begin{array}{c}0.03 \\
(1.30)\end{array}$ & $\begin{array}{c}0.03 \\
(1.19)\end{array}$ & $\begin{array}{c}0.11 \\
(3.60)\end{array}$ & $\begin{array}{l}-0.03 \\
(-0.92)\end{array}$ & $\begin{array}{c}0.07 \\
(3.37)\end{array}$ & $\begin{array}{c}-1.16 \\
(-1.76)\end{array}$ & $\begin{array}{c}0.73 \\
(1.40)\end{array}$ & $\begin{array}{l}-0.02 \\
(-2.23)\end{array}$ & $\begin{array}{c}0.01 \\
(1.54)\end{array}$ & $\begin{array}{c}0.00 \\
(-0.18)\end{array}$ & 0.64 \\
\hline Quin2 & $\begin{array}{c}0.80 \\
(5.16)\end{array}$ & $\begin{array}{c}0.37 \\
(4.49)\end{array}$ & $\begin{array}{c}0.31 \\
(15.66)\end{array}$ & $\begin{array}{c}0.03 \\
(1.33)\end{array}$ & $\begin{array}{c}0.01 \\
(0.58)\end{array}$ & $\begin{array}{c}0.11 \\
(4.44)\end{array}$ & $\begin{array}{c}0.02 \\
(0.59)\end{array}$ & $\begin{array}{c}0.03 \\
(1.82)\end{array}$ & $\begin{array}{l}-1.85 \\
(-3.48)\end{array}$ & $\begin{array}{c}-0.12 \\
(-0.30)\end{array}$ & $\begin{array}{l}-0.01 \\
(-2.28)\end{array}$ & $\begin{array}{c}0.01 \\
(1.45)\end{array}$ & $\begin{array}{c}0.00 \\
(-0.05)\end{array}$ & 0.73 \\
\hline Quin3 & $\begin{array}{c}0.72 \\
(4.06)\end{array}$ & $\begin{array}{c}0.26 \\
(3.10)\end{array}$ & $\begin{array}{c}0.36 \\
(18.28)\end{array}$ & $\begin{array}{c}0.04 \\
(2.28)\end{array}$ & $\begin{array}{c}0.04 \\
(1.98)\end{array}$ & $\begin{array}{c}0.14 \\
(5.92)\end{array}$ & $\begin{array}{l}-0.06 \\
(-2.27)\end{array}$ & $\begin{array}{c}0.04 \\
(2.65)\end{array}$ & $\begin{array}{l}-1.91 \\
(-3.58)\end{array}$ & $\begin{array}{c}-0.66 \\
(-1.55)\end{array}$ & $\begin{array}{l}-0.01 \\
(-1.31)\end{array}$ & $\begin{array}{c}0.01 \\
(1.41)\end{array}$ & $\begin{array}{c}0.00 \\
(-0.13)\end{array}$ & 0.80 \\
\hline Quin4 & $\begin{array}{c}0.64 \\
(3.78)\end{array}$ & $\begin{array}{c}0.24 \\
(3.00)\end{array}$ & $\begin{array}{c}0.34 \\
(18.09)\end{array}$ & $\begin{array}{c}0.05 \\
(2.48)\end{array}$ & $\begin{array}{c}0.02 \\
(0.87)\end{array}$ & $\begin{array}{c}0.12 \\
(5.09)\end{array}$ & $\begin{array}{l}-0.06 \\
(-2.26)\end{array}$ & $\begin{array}{c}0.00 \\
(-0.03)\end{array}$ & $\begin{array}{c}-1.77 \\
(-3.46)\end{array}$ & $\begin{array}{c}-0.19 \\
(-0.47)\end{array}$ & $\begin{array}{c}0.00 \\
(-0.31)\end{array}$ & $\begin{array}{c}0.01 \\
(1.35)\end{array}$ & $\begin{array}{c}0.00 \\
(-0.80)\end{array}$ & 0.80 \\
\hline High & $\begin{array}{c}0.36 \\
(2.17) \\
\end{array}$ & $\begin{array}{c}-0.03 \\
(-0.33) \\
\end{array}$ & $\begin{array}{c}0.31 \\
(15.58)\end{array}$ & $\begin{array}{c}0.02 \\
(1.24) \\
\end{array}$ & $\begin{array}{c}0.00 \\
(0.24) \\
\end{array}$ & $\begin{array}{c}0.10 \\
(4.25) \\
\end{array}$ & $\begin{array}{c}0.02 \\
(0.79) \\
\end{array}$ & $\begin{array}{c}-0.04 \\
(-2.84)\end{array}$ & $\begin{array}{c}-2.67 \\
(-4.99)\end{array}$ & $\begin{array}{c}-0.46 \\
(-1.08) \\
\end{array}$ & $\begin{array}{c}-0.01 \\
(-1.39)\end{array}$ & $\begin{array}{c}0.01 \\
(1.10) \\
\end{array}$ & $\begin{array}{c}0.00 \\
(-0.57)\end{array}$ & 0.77 \\
\hline $\mathrm{L}-\mathrm{H}$ & $\begin{array}{c}0.52 \\
(5.14)\end{array}$ & $\begin{array}{c}0.49 \\
(5.50)\end{array}$ & $\begin{array}{c}-0.01 \\
(-0.42)\end{array}$ & $\begin{array}{c}0.01 \\
(0.34)\end{array}$ & $\begin{array}{c}0.02 \\
(1.14)\end{array}$ & $\begin{array}{c}0.00 \\
(0.16)\end{array}$ & $\begin{array}{c}-0.05 \\
(-1.80)\end{array}$ & $\begin{array}{c}0.11 \\
(6.56)\end{array}$ & $\begin{array}{c}1.51 \\
(2.65)\end{array}$ & $\begin{array}{c}1.19 \\
(2.64)\end{array}$ & $\begin{array}{c}-0.01 \\
(-1.27)\end{array}$ & $\begin{array}{c}0.00 \\
(0.75)\end{array}$ & $\begin{array}{c}0.00 \\
(0.33)\end{array}$ & 0.31 \\
\hline
\end{tabular}

Panel B: Failure = LP_failure

\begin{tabular}{cccccccccccccccc}
$\begin{array}{c}\text { Failure } \\
\text { Risk }\end{array}$ & $\begin{array}{c}\text { Raw } \\
\text { Return }\end{array}$ & Alpha & MKTRF & LAG1 & LAG2 & SMB & HML & UMD & $\Delta$ DEF & $\Delta Y 10$ & PTFBD & PTFFX & PTFCOM & AdjR2 \\
Low & 0.84 & 0.43 & 0.27 & 0.01 & 0.01 & 0.10 & -0.03 & 0.08 & -0.71 & 0.79 & -0.02 & 0.01 & 0.00 & 0.61 \\
& $(5.64)$ & $(4.44)$ & $(11.44)$ & $(0.59)$ & $(0.33)$ & $(3.60)$ & $(-0.89)$ & $(4.40)$ & $(-1.13)$ & $(1.60)$ & $(-3.13)$ & $(2.02)$ & $(-0.06)$ & \\
Quin2 & 0.76 & 0.35 & 0.29 & 0.03 & 0.02 & 0.11 & 0.01 & 0.04 & -1.35 & 0.21 & -0.01 & 0.01 & 0.00 & 0.69 \\
& $(5.25)$ & $(4.23)$ & $(14.25)$ & $(1.42)$ & $(1.26)$ & $(4.42)$ & $(0.21)$ & $(2.30)$ & $(-2.51)$ & $(0.50)$ & $(-1.63)$ & $(1.17)$ & $(0.28)$ & \\
Quin3 & 0.79 & 0.32 & 0.36 & 0.04 & 0.03 & 0.16 & -0.06 & 0.05 & -2.35 & -0.91 & -0.01 & 0.01 & 0.00 & 0.78 \\
& $(4.27)$ & $(3.54)$ & $(16.68)$ & $(1.84)$ & $(1.52)$ & $(6.10)$ & $(-2.17)$ & $(3.07)$ & $(-4.00)$ & $(-1.97)$ & $(-1.23)$ & $(1.09)$ & $(-0.64)$ & \\
Quin4 & 0.65 & 0.23 & 0.37 & 0.03 & 0.02 & 0.12 & -0.03 & 0.00 & -2.10 & -0.54 & 0.00 & 0.01 & -0.01 & 0.79 \\
& $(3.69)$ & $(2.66)$ & $(18.10)$ & $(1.63)$ & $(0.99)$ & $(4.78)$ & $(-0.95)$ & $(-0.09)$ & $(-3.83)$ & $(-1.24)$ & $(-0.67)$ & $(1.50)$ & $(-0.94)$ & \\
High & 0.40 & 0.02 & 0.34 & 0.06 & 0.01 & 0.09 & 0.01 & -0.08 & -2.74 & -0.32 & 0.00 & 0.00 & 0.00 & 0.78 \\
& $(2.19)$ & $(0.26)$ & $(15.84)$ & $(2.67)$ & $(0.39)$ & $(3.36)$ & $(0.30)$ & $(-4.43)$ & $(-4.74)$ & $(-0.70)$ & $(-0.56)$ & $(0.83)$ & $(-0.26)$ & \\
\hline L-H & 0.44 & 0.41 & -0.07 & -0.04 & 0.00 & 0.01 & -0.04 & 0.16 & 2.03 & 1.11 & -0.02 & 0.01 & 0.00 & 0.47 \\
& $(3.29)$ & $(3.98)$ & $(-3.00)$ & $(-1.78)$ & $(-0.02)$ & $(0.47)$ & $(-1.11)$ & $(8.05)$ & $(3.08)$ & $(2.14)$ & $(-2.48)$ & $(1.19)$ & $(0.17)$ & \\
\hline
\end{tabular}

Notes: This table reports the results of monthly time-series regressions for quintile portfolios grouped by the predicted probability of fund failure. In Table 3, I explain how individual funds are grouped into quintiles. For each quintile portfolio, equally-weighted portfolio returns are computed in each month. In each panel, Low (High) denotes a quintile portfolio with the lowest (highest) failure risk. I report, as a percentage per month, both average raw return and risk-adjusted return (Alpha) for each portfolio. To compute alpha, I estimate the time-series regression model that consists of the following risk factors: seven factors by Fung and Hsieh (2004), book-to-market factor (HML), momentum factor (UMD), and two (1-month and 2-month) lagged excess market returns. Fund and Hsiehís seven factors include excess market returns (MKTRF), size factor (SMB), change in credit spreads (Moody's Baa yield minus 10-year treasury yield ( $\triangle \mathrm{DEF})$ ), change in 10-year treasury yields $(\triangle \mathrm{Y} 10)$, and three primitive trend-following factors on bond (PTFBD), currency (PTFFX), and commodity (PTFCOM). Credit spreads and 10-year treasury yields are multiplied by 100 . For parameters estimated from the regression, the first row reports the estimated parameter coefficients, and the second row reports corresponding t-statistics in parentheses. Adjusted R2 for each regression model is also reported. The time-series regressions are based on monthly portfolio returns from January 1997 to December 2012. Two definitions of hedge fund failure are considered: liquidation (Panel A) and LP_failure (Panel B). The return regressions are implemented after removing last two monthly returns for failed funds. 


\subsection{Failure Probability and Hedge Fund Performance: Panel Regression}

In this subsection, I estimate a panel regression with two-way (fund and month) clustered errors to examine how a hedge fund's probability of failure affects its one-month-ahead future return. By using a panel regression, I can examine whether the previously documented negative effect of a hedge fund's failure probability on its future return still remains after adjusting for the effect of fund-level variables on future performance. Furthermore, the two-way clustered errors suggested by Petersen (2009) ensure a robust standard error for the negative effect.

In Panel A (where failure means liquidation), Model 1 examines the effect of Rank of failure prob $_{i, t}$ on future performance, where Rankof failure prob $_{i, t}$ is a rank variable of the predicted failure probability ranging from 1 (lowest failure probability) to 5 (highest failure probability).26) The estimated coefficient of -0.11 $(\mathrm{t}-\mathrm{stat}=-4.21)$ implies that a hedge fund's future monthly return could go down by $0.44 \%(=4 \times 0.11 \%)$ as the fund's failure probability rank goes up from 1 to 5 .

Bali, et al. (2014) proposes a new measure of macroeconomic uncertainty and shows that the macroeconomic uncertainty betas explain a significant proportion of the cross-sectional dispersion in hedge fund returns. Thus, one may be curious about whether the probability of fund failure is related to the macroeconomic uncertainty beta.27) Therefore, I estimate each fund's macroeconomic uncertainty beta (Macro-beta)28) as in Bali, et al. (2014) and include it in Model 2. To make Macro-beta comparable with the rank variable of failure probability in Model 1, the estimated Macro-beta is transformed into Rankof Macro- beta ${ }_{i, t}$, which is a rank variable of Macro-beta ranging from 1 (lowest Macro-beta) to 5 (highest Macro-beta). Consistent with the result in Bali, et al. (2014), I also find a positive

26) Using the predicted failure probability directly can create an errors-in-variables problem because the predicted failure probability is measured with errors. By using the rank variable, the potential errors-in-variables problem can be mitigated. Kisgen (2006) also uses a similar approach to reduce a potential errors-in-variables complication in his credit score measure.

27) Bali, et al. (2011) shows a positive link between default spread beta (DEF-beta) and future hedge fund returns. Intuitively, a fund's DEF-beta is more likely to be related to its probability of failure. Thus, I add a fund's DEF-beta to the specification of Model 2 and find that the effect of DEF-beta on future fund returns is subsumed by the effect of Macro-beta on future fund returns and becomes insignificant. This unreported table is available upon request.

28) I thank Turan Bali for making macroeconomic uncertainty index available for download. 
Table 6: Failure Risk and the Cross-Section of Hedge Fund Returns

\begin{tabular}{|c|c|c|c|c|c|c|}
\hline \multirow[b]{2}{*}{ Variable } & \multicolumn{3}{|c|}{ Panel A: Failure = Liquidation } & \multicolumn{3}{|c|}{ Panel $\mathrm{B}$ : Failure $=\mathrm{LP}$ _failure } \\
\hline & Model 1 & Model 2 & Model 3 & Model 1 & Model 2 & Model 3 \\
\hline Rank of failure prob & $\begin{array}{l}-0.11^{* * *} \\
(-4.21)\end{array}$ & $\begin{array}{l}-0.10^{* * *} \\
(-3.79)\end{array}$ & $\begin{array}{l}-0.10^{* * *} \\
(-3.56)\end{array}$ & $\begin{array}{l}-0.09^{* * *} \\
(-2.71)\end{array}$ & $\begin{array}{l}-0.07^{* *} \\
(-2.31)\end{array}$ & $\begin{array}{l}-0.07^{* *} \\
(-2.32)\end{array}$ \\
\hline Rank of Macro-beta & & $\begin{array}{l}0.20^{* * *} \\
(3.41)\end{array}$ & $\begin{array}{l}0.15^{* * *} \\
(2.67)\end{array}$ & & $\begin{array}{l}0.21^{* * *} \\
(3.55)\end{array}$ & $\begin{array}{l}0.15^{* * *} \\
(2.74)\end{array}$ \\
\hline Lagged return & & & $\begin{array}{l}15.16^{* * *} \\
(3.69)\end{array}$ & & & $\begin{array}{l}15.33^{* * *} \\
(3.75)\end{array}$ \\
\hline Volatility & & & $\begin{array}{c}4.91 \\
(1.18)\end{array}$ & & & $\begin{array}{l}5.50 \\
(1.35)\end{array}$ \\
\hline Skewness & & & $\begin{array}{l}-0.01 \\
(-0.20)\end{array}$ & & & $\begin{array}{l}-0.02 \\
(-0.31)\end{array}$ \\
\hline Kurtosis & & & $\begin{array}{c}0.02 \\
(1.02)\end{array}$ & & & $\begin{array}{c}0.01 \\
(0.93)\end{array}$ \\
\hline Age & & & $\begin{array}{c}0.00 \\
(0.12)\end{array}$ & & & $\begin{array}{c}0.00 \\
(0.37)\end{array}$ \\
\hline Size & & & $\begin{array}{l}-0.08^{* * *} \\
(-3.26)\end{array}$ & & & $\begin{array}{l}-0.08^{* * *} \\
(-2.84)\end{array}$ \\
\hline Management fee & & & $\begin{array}{c}0.03 \\
(0.37)\end{array}$ & & & $\begin{array}{c}0.03 \\
(0.42)\end{array}$ \\
\hline Incentive fee & & & $\begin{array}{c}0.01^{*} \\
(1.95)\end{array}$ & & & $\begin{array}{c}0.01 \\
(1.63)\end{array}$ \\
\hline Redemption period & & & $\begin{array}{c}0.00 \\
(1.05)\end{array}$ & & & $\begin{array}{r}0.00^{*} \\
(1.86)\end{array}$ \\
\hline Minimum investment & & & $\begin{array}{c}0.00 \\
(0.41)\end{array}$ & & & $\begin{array}{c}0.00 \\
(0.40)\end{array}$ \\
\hline Dummy lockup & & & $\begin{array}{c}0.00 \\
(0.01)\end{array}$ & & & $\begin{array}{c}0.05 \\
(0.94)\end{array}$ \\
\hline Dummy leverage & & & $\begin{array}{c}0.01 \\
(0.18)\end{array}$ & & & $\begin{array}{c}0.01 \\
(0.18)\end{array}$ \\
\hline Intercept & $\begin{array}{l}0.77^{* * *} \\
(4.26)\end{array}$ & $\begin{array}{l}0.11^{* * *} \\
(0.41)\end{array}$ & $\begin{array}{c}0.07 \\
(0.30)\end{array}$ & $\begin{array}{l}0.73^{* * *} \\
(4.62)\end{array}$ & $\begin{array}{c}0.04 \\
(0.20)\end{array}$ & $\begin{array}{l}-0.07 \\
(-0.40)\end{array}$ \\
\hline
\end{tabular}

Notes: This table reports the results from panel regressions with two-way (fund-month) clustered errors suggested by Petersen (2009). For each panel regression, the dependent variable is an individual hedge fund's monthly excess return over 1-month T-bill rate. I multiply the excess return by 100 to make it a percentage number. Rank of failure prob is a rank variable of the predicted failure probability, ranging from 1 to 5 . Similarly, Rank of Macro-beta is a rank variable of Macro-beta estimates, ranging from 1 to 5 . The Macro-beta is based on a measure of macroeconomic uncertainty proposed by Bali, Brown, and Caglayan (2014). Other variables are defined in Table 1. Size variable is included in the regression model after taking a log transformation. Sample period is from January 1997 to December 2012. * indicates statistical significance at the $10 \%$ level, $* *$ at the $5 \%$ level, and $* * *$ at the $1 \%$ level. Two definitions of hedge fund failure are considered: liquidation (Panel A) and LP_failure (Panel B). The return regressions are implemented after removing last two monthly returns for failed funds. 
effect (coefficient of $0.20 \%$ per month with t-stat $=3.41$ ) of Macro-beta on future hedge fund returns. But the negative effect (coefficient of $-0.10 \%$ per month with t-stat $=-3.79$ ) of failure probability on future fund returns still holds, suggesting that the two variables, failure probability and Macro-beta, affect future hedge fund returns independently.

Model 3 includes fund-level control variables suggested by Bali, et al. (2012) and reports that the estimated coefficient on Rank of failure prob $_{i, t}$ is $-0.10 \%$ per month (t-stat=-3.56). Therefore, the negative effect of failure probability on future hedge fund returns is economically and statistically significant even after controlling for a large number of fund-level variables. Furthermore, the negative effect is robust to the definition of hedge fund failures according to the results reported in Panel B (where failure is defined by LP-failure).

\subsection{The Effect of Each Covariate Variable on Future Hedge Fund Returns}

Since a hedge fund's probability of failure is a combination of fund-level variables included in the failure prediction model, one may wonder how each fund-level variable included in the failure prediction model affects future fund returns. Table 7 reports results from twelve univariate panel regressions with two-way (fund and month) clustered errors. Among the twelve fund-level variables, only four variables - Size[t-1], Volatility[t-24,t-1], Redemption period, and Dummy lockup - show at least weakly significant effect on future fund returns. However, these four variables are used as fund-level control variables in Model 3 of Table 6 where the negative effect of failure probability on future fund returns is largely robust to the effect of these fund-level variables on future fund returns. Therefore, it is reasonable to conclude that a negative link between failure probability and future hedge fund returns is not driven by the effect of any single variable included in the failure prediction model on future fund returns. 


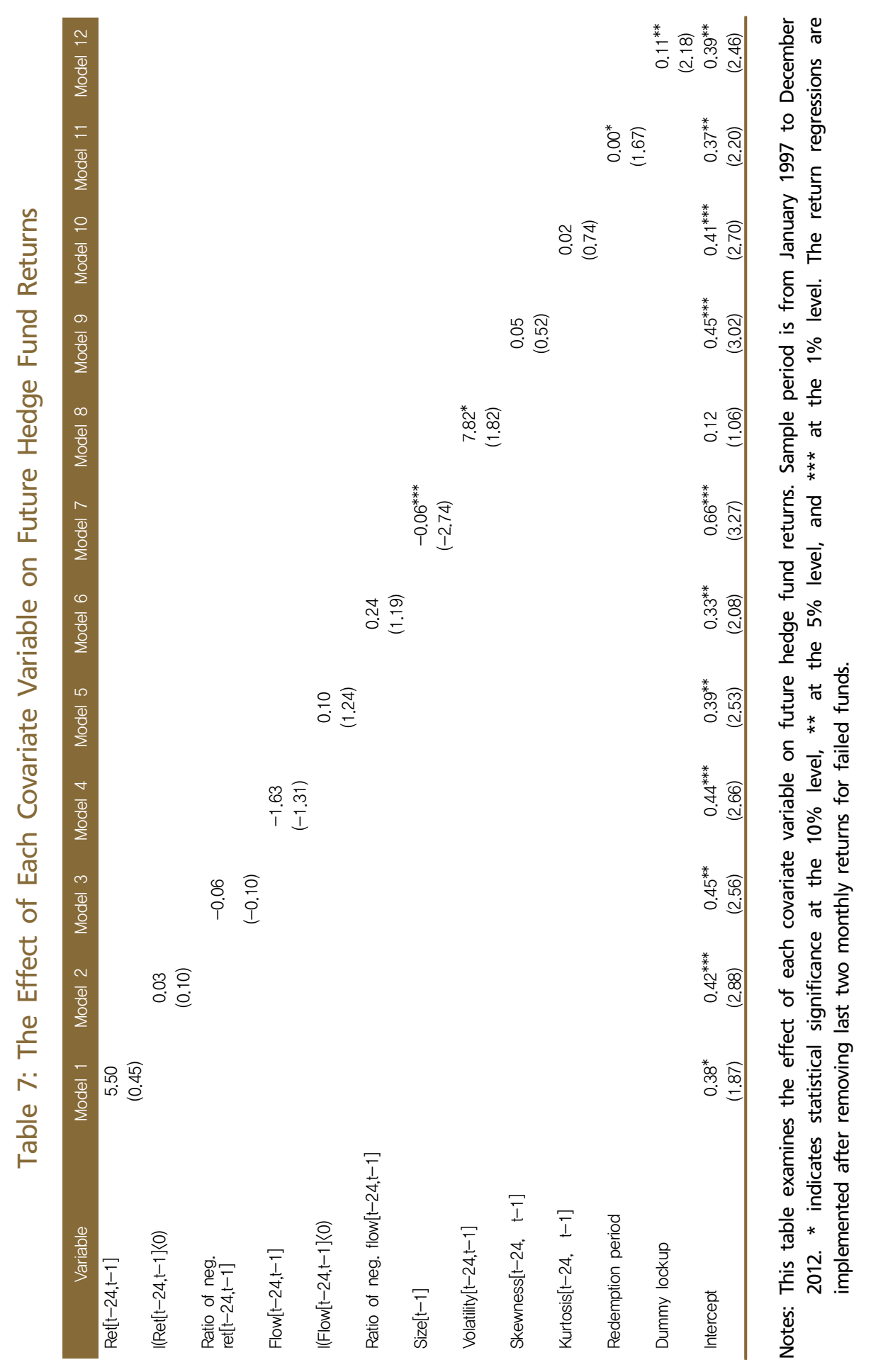




\subsection{Why do Hedge Funds with High Failure Probability Underperform?}

Why do hedge funds perform poorly when their failure probability is high? As a hedge fund becomes concerned with its investors' withdrawal of capital due to the fund's poor performance, it may be forced to change its investment policy. In particular, it might be forced to sell off some of its illiquid asset positions potentially at fire-sale prices in order to meet increased redemption requests. If the fund has strong share restrictions, such as lockup restrictions and long redemption notice periods, the strong restrictions could help mitigating the negative impact of fund outflows on future performance because the fund could avoid making a suboptimal investment decision just to meet redemption requests. Thus, the negative relation between failure risk and future performance is expected to be larger for funds with weaker share restrictions.

To examine whether hedge funds with weak share restrictions underperform significantly when their failure risk is high, I use a double-sort approach. At the beginning of each month, I sort all funds into two groups by the degree (strong vs. weak) of share restrictions, and then sort the funds in each group into tertiles by their probability of failure. Strong share restrictions are defined as having a lockup and requiring at least 30-day redemption notice periods, while weak share restrictions are defined as having no lockup and requiring less-than-30-day redemption notice periods. Panel A (where failure means liquidation) of Table 8 shows that the return spread between the two extreme tertile groups by failure probability among hedge funds with weak share restrictions is $0.40 \%$ per month with $\mathrm{t}$-stat $=3.13($ alpha spread $=0.31 \%$ per month with $\mathrm{t}$-stat $=2.75)$, while the same return spread within funds with strong share restrictions is only $0.11 \%$ per month with $\mathrm{t}$-stat $=1.11$ (alpha spread $=0.11 \%$ per month with $\mathrm{t}$-stat $=1.42)$. Therefore, the results suggest that the negative impact of failure risk on future performance is driven by fund outflows following poor performance and is amplified when funds have weak share restrictions. 


\section{Table 8: Interaction Effect of Failure Risk and Share Restrictions on Hedge Fund Returns}

Panel A: Failure = Liquidation

\begin{tabular}{lccccc} 
& \multicolumn{2}{c}{ Panel A-1: Raw return } & & \multicolumn{2}{c}{ Panel A-2: Alpha } \\
\cline { 2 - 3 } \cline { 5 - 5 } Failure Risk & The Degree of Share Restrictions & & The Degree of Share Restrictions \\
\cline { 2 - 3 } Low & Weak & Strong & & Weak & Strong \\
\multirow{3}{*}{ Middle } & 0.72 & 0.87 & 0.29 & 0.45 \\
& $(4.10)$ & $(5.35)$ & $(2.58)$ & $(4.66)$ \\
High & 0.51 & 0.83 & 0.07 & 0.38 \\
& $(2.91)$ & $(4.50)$ & $(0.70)$ & $(4.18)$ \\
& 0.32 & 0.75 & -0.02 & 0.34 \\
$\mathrm{~L}-\mathrm{H}$ & $(1.95)$ & $(4.23)$ & $(-0.23)$ & $(4.09)$ \\
& 0.40 & 0.11 & 0.31 & 0.11 \\
& $(3.13)$ & $(1.11)$ & $(2.75)$ & $(1.42)$ \\
\hline
\end{tabular}

Panel B: Failure $=$ LP_failure

\begin{tabular}{lccccc} 
& \multicolumn{2}{c}{ Panel B-1: Raw return } & & \multicolumn{2}{c}{ Panel B-2: Alpha } \\
\cline { 2 - 3 } Failure Risk & The Degree of Share Restrictions & & The Degree of Share Restrictions \\
\cline { 2 - 3 } Low & Weak & Strong & Weak & Strong \\
\multirow{3}{*}{ Middle } & 0.67 & $(5.44)$ & 0.25 & 0.43 \\
& $(3.92)$ & 0.87 & $(2.22)$ & $(4.62)$ \\
High & 0.59 & $(4.96)$ & 0.17 & 0.43 \\
& $(3.42)$ & 0.76 & $(1.58)$ & $(4.62)$ \\
& 0.33 & $(3.84)$ & -0.05 & 0.34 \\
$\mathrm{~L}-\mathrm{H}$ & $(1.88)$ & 0.09 & $(-0.48)$ & $(3.75)$ \\
\hline
\end{tabular}

Notes: This table reports the interaction effect of failure risk and share restrictions on future fund returns. At the beginning of each month, I sort all funds into two groups based on the degree (strong vs. weak) of share restrictions, then sort funds in each group into tertiles by their predicted failure probability. Strong share restrictions are defined as having a lockup and requiring at least 30-day redemption notice periods, while weak share restrictions are defined as having no lockup and requiring less-than-30-day redemption notice periods. For each of the six portfolios, I compute equally-weighted portfolio returns every month and examine their average raw return and risk-adjusted return using the time-series regression model described in Table 5. For each regression model, I report a portfolio's raw and risk-adjusted return as a percentage per month and its corresponding t-statistic in parenthesis. The time-series regressions are based on monthly portfolio returns from January 1997 to December 2012. Two definitions of hedge fund failure are considered: liquidation (Panel A) and LP_failure (Panel B). The return regressions are implemented after removing last two monthly returns for failed funds. 


\section{Robustness Tests}

\subsection{Specifications of Failure Prediction Model}

In the previous section, a fixed failure prediction model (in Table 2) is used to document a negative link between failure probability and future fund returns. In this subsection, I examine whether the negative link still holds even when several important failure predictors (e.g., past performance and fund flow) are dropped in the failure prediction model. I first drop $k(k=3,6$, and 8$)$ number of predictors in the original failure prediction model. With the modified failure prediction model, each fund's failure probability is newly estimated. Then, the relationship between failure probability and future hedge fund returns is examined in the same manner as in the previous section.

Table 9 reports the return/alpha spread between the two extreme quintile portfolios based on failure probability without $k$ variables. When $k=3$, I drop Ret[t-24, t-1], Flow[t-24, t-1] and Size[t-1]. Based on the failure probability without information on past performance level, fund flow level, and fund size, the results support the negative link between failure probability and future fund returns (the alpha spread is $0.48 \%$ per month in Panel A where failure means liquidation). When $k=6$, I drop three additional variables, I $(\operatorname{Ret}[\mathrm{t}-24, \mathrm{t}-1]<0), \mathrm{I}(\operatorname{Flow}[\mathrm{t}-24, \mathrm{t}-1]<0)$ and Skewness[t-24, t-1]. Using this failure probability without information on the nonlinear effect of past performance and fund flow on fund failure, the alpha spread is slightly reduced to $0.45 \%$ per month. When $k=8$, I drop two additional variables, Ratio of negative ret[t-24,t-1] and Ratio of negative flow[t-24,t-1]. Using this failure probability without information on past performance and fund flow, the alpha spread is reduced further to $0.25 \%$ per month, but still statistically significant. Therefore, any reasonable failure prediction model is good enough for predicting a negative link between failure probability and future fund returns. Furthermore, a failure prediction model with at least one set of past performance and fund flow will help better predicting the cross-section of future hedge fund returns. 
Table 9: Failure Prediction Models without Important Predictors

Panel A: Failure = Liquidation

\begin{tabular}{|c|c|c|c|c|c|c|}
\hline \multirow[b]{2}{*}{ Failure Risk } & \multicolumn{2}{|c|}{ (1) w/o 3 variables } & \multicolumn{2}{|c|}{ (2) w/o 6 variables } & \multicolumn{2}{|c|}{ (3) w/o 8 variables } \\
\hline & Raw Return & Alpha & Raw Return & Alpha & Raw Return & Alpha \\
\hline \multirow[t]{2}{*}{ Low } & 0.87 & 0.46 & 0.88 & 0.47 & 0.81 & 0.41 \\
\hline & $(5.45)$ & $(4.66)$ & $(5.69)$ & $(5.04)$ & $(4.77)$ & $(4.02)$ \\
\hline \multirow[t]{2}{*}{ Quin2 } & 0.81 & 0.38 & 0.80 & 0.39 & 0.75 & 0.34 \\
\hline & $(5.31)$ & $(4.77)$ & (5.11) & $(4.41)$ & $(5.03)$ & (4.19) \\
\hline \multirow[t]{2}{*}{ Quin3 } & 0.73 & 0.27 & 0.75 & 0.30 & 0.71 & 0.28 \\
\hline & $(4.28)$ & (3.37) & $(4.49)$ & $(3.70)$ & $(4.38)$ & (3.57) \\
\hline \multirow[t]{2}{*}{ Quin4 } & 0.65 & 0.22 & 0.66 & 0.23 & 0.67 & 0.23 \\
\hline & (3.66) & $(2.66)$ & (3.78) & (2.95) & $(3.80)$ & (2.95) \\
\hline \multirow[t]{2}{*}{ High } & 0.34 & -0.03 & 0.40 & 0.02 & 0.56 & 0.16 \\
\hline & $(2.07)$ & $(-0.33)$ & (2.51) & $(0.27)$ & (3.55) & $(1.81)$ \\
\hline \multirow[t]{2}{*}{$\mathrm{L}-\mathrm{H}$} & 0.53 & 0.48 & 0.48 & 0.45 & 0.26 & 0.25 \\
\hline & $(6.03)$ & $(6.06)$ & $(5.80)$ & $(5.57)$ & $(2.89)$ & $(2.73)$ \\
\hline \multicolumn{7}{|c|}{ Panel B: Failure = LP_failure } \\
\hline \multirow[b]{2}{*}{ Failure Risk } & \multicolumn{2}{|c|}{ (1) w/o 3 variables } & \multicolumn{2}{|c|}{ (2) w/o 6 variables } & \multicolumn{2}{|c|}{ (3) w/o 8 variables } \\
\hline & Raw Return & Alpha & Raw Return & Alpha & Raw Return & Alpha \\
\hline \multirow[t]{2}{*}{ Low } & 0.88 & 0.47 & 0.85 & 0.45 & 0.76 & 0.36 \\
\hline & (6.52) & $(5.41)$ & $(6.71)$ & $(5.57)$ & $(4.99)$ & (3.83) \\
\hline \multirow[t]{2}{*}{ Quin2 } & 0.79 & 0.39 & 0.80 & 0.38 & 0.77 & 0.36 \\
\hline & $(5.43)$ & $(4.50)$ & (5.29) & (4.33) & $(5.14)$ & $(4.26)$ \\
\hline \multirow[t]{2}{*}{ Quin3 } & 0.78 & 0.31 & 0.81 & 0.36 & 0.77 & 0.34 \\
\hline & $(4.44)$ & (3.61) & $(4.70)$ & $(4.28)$ & $(4.80)$ & $(4.20)$ \\
\hline \multirow[t]{2}{*}{ Quin4 } & 0.63 & 0.18 & 0.63 & 0.19 & 0.65 & 0.21 \\
\hline & $(3.30)$ & $(2.01)$ & (3.30) & $(2.07)$ & (3.65) & $(2.56)$ \\
\hline \multirow[t]{2}{*}{ High } & 0.37 & 0.00 & 0.45 & 0.07 & 0.60 & 0.19 \\
\hline & $(1.98)$ & $(0.01)$ & $(2.63)$ & $(0.90)$ & $(3.44)$ & $(2.04)$ \\
\hline \multirow[t]{2}{*}{$\mathrm{L}-\mathrm{H}$} & 0.51 & 0.47 & 0.39 & 0.38 & 0.16 & 0.18 \\
\hline & (3.94) & $(5.04)$ & (3.70) & $(4.85)$ & $(1.55)$ & (1.90) \\
\hline
\end{tabular}

Notes: This table reports the results of monthly time-series regressions for quintile portfolios grouped by the predicted probability of fund failure. But failure prediction models are estimated without several important predictors. In Panel AVB-(1), three variables (Ret[t-24, t-1], Flow[t-24, $\mathrm{t}-1]$ and Size[t-1]) are dropped from the original failure prediction model reported in Table 2. With the modified failure prediction model, a fund's failure probability is newly estimated. In Panel AVB-(2), three additional variables (I(Ret[t-24,t-1]<0), I(Flow $[t-24, t-1]<0)$ and Skewness $[t-24$, $\mathrm{t}-1]$ )) are dropped from the model (1). In Panel AVB-(3), another two variables (Ratio of negative ret[t-24,t-1] and Ratio of negative flow[t-24,t-1]) are dropped from the model (2). The time-series regressions are based on monthly portfolio returns from January 1997 to December 2012. Two definitions of hedge fund failure are considered: liquidation (Panel $A$ ) and LP_failure (Panel B). The detailed explanations for portfolio formation and for time-series regressions are given in Table 3 and Table 5, respectively. 


\subsection{Investment Styles}

In this subsection, I examine whether hedge funds' investment styles affect a negative link between failure probability and future fund returns. Following prior literature (e.g., Bali, et al. (2014)), hedge funds can be grouped into three investment styles: (1) directional (dedicated short bias, emerging markets, and global macro), (2) semi-directional (event driven, multi-strategy, and long/short equity hedge), and (3) non-directional (convertible arbitrage, equity market neutral, and fixed income arbitrage).

Table 10 reports that the negative link between failure probability and future fund returns is found in all of three investment styles. Furthermore, the negative effect of failure risk on future fund returns is stronger within directional funds than within the other styles. In Panel B (where failure means LP_failure), the alpha spread within directional funds is $0.71 \%$ per month while the alpha spread within semi-directional funds is $0.35 \%$ and the alpha spread within non-directional funds is $0.32 \%$.

\subsection{On-shore Funds vs. Off-shore Funds}

The sample in this paper has a potential to include more cross-sectional observations than the actual number of separate funds because both on-shore and off-shore funds are included in the sample. If a hedge fund has both an on-shore fund and an off-shore fund, then two cross-sectional observations may appear in my sample during the same time period. To mitigate the duplicated funds issue, I divide the samples into two groups, on-shore funds and off-shore funds, and then examine the relationship between failure probability and future fund returns within each group. Table 11 confirms the significantly negative link between failure probability and future fund returns in both on-shore funds and off-shore funds. Therefore, the duplicated funds issue is less likely to be the concern for the main result in this paper. 
Table 10: Investment Styles - Directional, Semi-directional, and Non-directional

\begin{tabular}{|c|c|c|c|c|c|c|}
\hline \multirow[b]{2}{*}{$\begin{array}{l}\text { Failure } \\
\text { Risk }\end{array}$} & \multicolumn{2}{|c|}{ (1) Directional } & \multicolumn{2}{|c|}{ (2) Semi-directional } & \multicolumn{2}{|c|}{ (3) Non-directional } \\
\hline & $\begin{array}{c}\text { Raw } \\
\text { Return }\end{array}$ & Alpha & $\begin{array}{c}\text { Raw } \\
\text { Return }\end{array}$ & Alpha & $\begin{array}{c}\text { Raw } \\
\text { Return }\end{array}$ & Alpha \\
\hline Low & $\begin{array}{l}1.00 \\
(3.50)\end{array}$ & $\begin{array}{l}0.48 \\
(2.00)\end{array}$ & $\begin{array}{l}0.86 \\
(4.76)\end{array}$ & $\begin{array}{l}0.42 \\
(4.17)\end{array}$ & $\begin{array}{l}0.61 \\
(7.84)\end{array}$ & $\begin{array}{l}0.36 \\
(5.19)\end{array}$ \\
\hline Quin2 & $\begin{array}{l}0.79 \\
(3.67)\end{array}$ & $\begin{array}{l}0.37 \\
(2.32)\end{array}$ & $\begin{array}{l}0.80 \\
(4.59)\end{array}$ & $\begin{array}{l}0.36 \\
(4.21)\end{array}$ & $\begin{array}{l}0.65 \\
(8.22)\end{array}$ & $\begin{array}{l}0.35 \\
(5.80)\end{array}$ \\
\hline Quin3 & $\begin{array}{l}0.77 \\
(3.70)\end{array}$ & $\begin{array}{l}0.33 \\
(2.06)\end{array}$ & $\begin{array}{l}0.75 \\
(4.16)\end{array}$ & $\begin{array}{l}0.25 \\
(3.03)\end{array}$ & $\begin{array}{l}0.53 \\
(6.27)\end{array}$ & $\begin{array}{l}0.23 \\
(3.62)\end{array}$ \\
\hline Quin4 & $\begin{array}{l}0.54 \\
(2.35)\end{array}$ & $\begin{array}{l}0.16 \\
(0.93)\end{array}$ & $\begin{array}{l}0.74 \\
(3.83)\end{array}$ & $\begin{array}{l}0.28 \\
(3.56)\end{array}$ & $\begin{array}{l}0.58 \\
(7.42)\end{array}$ & $\begin{array}{l}0.31 \\
(5.04)\end{array}$ \\
\hline High & $\begin{array}{l}0.36 \\
(1.63)\end{array}$ & $\begin{array}{l}-0.01 \\
(-0.05)\end{array}$ & $\begin{array}{l}0.50 \\
(2.66) \\
\end{array}$ & $\begin{array}{l}0.09 \\
(1.07) \\
\end{array}$ & $\begin{array}{l}0.24 \\
(1.71)\end{array}$ & $\begin{array}{l}-0.07 \\
(-0.66)\end{array}$ \\
\hline $\mathrm{L}-\mathrm{H}$ & $\begin{array}{l}0.64 \\
(2.71)\end{array}$ & $\begin{array}{l}0.49 \\
(2.37)\end{array}$ & $\begin{array}{l}0.36 \\
(3.26)\end{array}$ & $\begin{array}{l}0.34 \\
(3.41)\end{array}$ & $\begin{array}{l}0.37 \\
(3.12)\end{array}$ & $\begin{array}{l}0.42 \\
(4.01)\end{array}$ \\
\hline
\end{tabular}

Panel B: Failure = LP_failure

\begin{tabular}{|c|c|c|c|c|c|c|}
\hline \multirow[b]{2}{*}{$\begin{array}{l}\text { Failure } \\
\text { Risk }\end{array}$} & \multicolumn{2}{|c|}{ (1) Directional } & \multicolumn{2}{|c|}{ (2) Semi-directional } & \multicolumn{2}{|c|}{ (3) Non-directional } \\
\hline & $\begin{array}{c}\text { Raw } \\
\text { Return }\end{array}$ & Alpha & $\begin{array}{c}\text { Raw } \\
\text { Return }\end{array}$ & Alpha & $\begin{array}{c}\text { Raw } \\
\text { Return }\end{array}$ & Alpha \\
\hline Low & $\begin{array}{l}1.10 \\
(4.03)\end{array}$ & $\begin{array}{l}0.62 \\
(2.64)\end{array}$ & $\begin{array}{l}0.83 \\
(5.39)\end{array}$ & $\begin{array}{l}0.39 \\
(4.31)\end{array}$ & $\begin{array}{l}0.69 \\
(8.89)\end{array}$ & $\begin{array}{l}0.42 \\
(6.15)\end{array}$ \\
\hline Quin2 & $\begin{array}{l}0.83 \\
(4.00)\end{array}$ & $\begin{array}{l}0.38 \\
(2.24)\end{array}$ & $\begin{array}{l}0.80 \\
(4.94)\end{array}$ & $\begin{array}{l}0.37 \\
(4.25)\end{array}$ & $\begin{array}{l}0.59 \\
(8.68)\end{array}$ & $\begin{array}{l}0.29 \\
(5.29)\end{array}$ \\
\hline Quin3 & $\begin{array}{l}0.74 \\
(3.45)\end{array}$ & $\begin{array}{l}0.30 \\
(1.90)\end{array}$ & $\begin{array}{l}0.79 \\
(4.24)\end{array}$ & $\begin{array}{l}0.30 \\
(3.34)\end{array}$ & $\begin{array}{l}0.57 \\
(6.80)\end{array}$ & $\begin{array}{l}0.28 \\
(4.08)\end{array}$ \\
\hline Quin4 & $\begin{array}{l}0.59 \\
(2.42)\end{array}$ & $\begin{array}{l}0.18 \\
(1.01)\end{array}$ & $\begin{array}{l}0.82 \\
(3.95)\end{array}$ & $\begin{array}{l}0.33 \\
(3.84)\end{array}$ & $\begin{array}{l}0.51 \\
(5.26)\end{array}$ & $\begin{array}{l}0.23 \\
(3.12)\end{array}$ \\
\hline High & $\begin{array}{l}0.29 \\
(1.23)\end{array}$ & $\begin{array}{l}-0.09 \\
(-0.51)\end{array}$ & $\begin{array}{l}0.45 \\
(2.14)\end{array}$ & $\begin{array}{l}0.04 \\
(0.46)\end{array}$ & $\begin{array}{l}0.38 \\
(3.00)\end{array}$ & $\begin{array}{l}0.10 \\
(1.25)\end{array}$ \\
\hline $\mathrm{L}-\mathrm{H}$ & $\begin{array}{l}0.81 \\
(3.47)\end{array}$ & $\begin{array}{l}0.71 \\
(3.40)\end{array}$ & $\begin{array}{l}0.38 \\
(2.75)\end{array}$ & $\begin{array}{l}0.35 \\
(3.39)\end{array}$ & $\begin{array}{l}0.31 \\
(2.70)\end{array}$ & $\begin{array}{l}0.32 \\
(3.22)\end{array}$ \\
\hline
\end{tabular}

Notes: This table reports the results of monthly time-series regressions for quintile portfolios grouped by the predicted probability of fund failure. The original failure prediction model (in Table 2) without style indictors is estimated within each style group: directional (dedicated short bias, emerging markets, and global macro), semi-directional (event driven, multi-strategy, and long/short equity hedge), or non-directional (convertible arbitrage, equity market neutral, and fixed income arbitrage). The time-series regressions are based on monthly portfolio returns from January 1997 to December 2012. Two definitions of hedge fund failure are considered: liquidation (Panel A) and LP_failure (Panel B). The detailed explanations for portfolio formation and for time-series regressions are given in Table 3 and Table 5, respectively. The return regressions are implemented after removing last two monthly returns for failed funds. 


\section{Table 11: On-shore Funds vs. Off-shore Funds}

Panel A: Failure = Liquidation

\begin{tabular}{|c|c|c|c|c|}
\hline \multirow[b]{2}{*}{ Failure Risk } & \multicolumn{2}{|c|}{ (1) On-shore } & \multicolumn{2}{|c|}{ (2) Off-shore } \\
\hline & Raw Return & Alpha & Raw Return & Alpha \\
\hline \multirow[t]{2}{*}{ Low } & 0.92 & 0.49 & 0.85 & 0.42 \\
\hline & (5.62) & (4.98) & $(4.77)$ & (3.54) \\
\hline \multirow[t]{2}{*}{ Quin2 } & 0.88 & 0.43 & 0.72 & 0.31 \\
\hline & (5.64) & (5.51) & $(4.51)$ & (3.20) \\
\hline \multirow[t]{2}{*}{ Quin3 } & 0.76 & 0.26 & 0.69 & 0.25 \\
\hline & $(4.17)$ & (3.31) & (3.93) & (2.78) \\
\hline \multirow[t]{2}{*}{ Quin4 } & 0.72 & 0.31 & 0.60 & 0.20 \\
\hline & $(4.15)$ & (4.35) & (3.50) & (2.07) \\
\hline \multirow[t]{2}{*}{ High } & 0.44 & 0.01 & 0.31 & -0.05 \\
\hline & (2.37) & $(0.16)$ & (1.99) & $(-0.58)$ \\
\hline \multirow[t]{2}{*}{$\mathrm{L}-\mathrm{H}$} & 0.48 & 0.47 & 0.54 & 0.47 \\
\hline & (3.74) & (4.14) & $(5.02)$ & (5.29) \\
\hline
\end{tabular}

Panel B: Failure = LP_failure

\begin{tabular}{|c|c|c|c|c|}
\hline \multirow[b]{2}{*}{ Failure Risk } & \multicolumn{2}{|c|}{ (1) On-shore } & \multicolumn{2}{|c|}{ (2) Off-shore } \\
\hline & Raw Return & Alpha & Raw Return & Alpha \\
\hline Low & $\begin{array}{l}0.90 \\
(6.08)\end{array}$ & $\begin{array}{l}0.47 \\
(5.07)\end{array}$ & $\begin{array}{l}0.79 \\
(4.76)\end{array}$ & $\begin{array}{l}0.39 \\
(3.21)\end{array}$ \\
\hline Quin2 & $\begin{array}{l}0.83 \\
(5.59)\end{array}$ & $\begin{array}{l}0.40 \\
(4.94)\end{array}$ & $\begin{array}{l}0.69 \\
(4.74)\end{array}$ & $\begin{array}{l}0.30 \\
(3.23)\end{array}$ \\
\hline Quin3 & $\begin{array}{l}0.83 \\
(4.39)\end{array}$ & $\begin{array}{l}0.34 \\
(3.82)\end{array}$ & $\begin{array}{l}0.77 \\
(4.22)\end{array}$ & $\begin{array}{l}0.33 \\
(3.33)\end{array}$ \\
\hline Quin4 & $\begin{array}{l}0.79 \\
(4.41)\end{array}$ & $\begin{array}{l}0.33 \\
(4.17)\end{array}$ & $\begin{array}{l}0.57 \\
(3.11)\end{array}$ & $\begin{array}{l}0.16 \\
(1.60)\end{array}$ \\
\hline High & $\begin{array}{l}0.45 \\
(2.30)\end{array}$ & $\begin{array}{l}0.06 \\
(0.68)\end{array}$ & $\begin{array}{l}0.36 \\
(2.04)\end{array}$ & $\begin{array}{l}-0.01 \\
(-0.11)\end{array}$ \\
\hline$L-H$ & $\begin{array}{l}0.44 \\
(2.82)\end{array}$ & $\begin{array}{l}0.41 \\
(3.39)\end{array}$ & $\begin{array}{l}0.43 \\
(3.29)\end{array}$ & $\begin{array}{l}0.40 \\
(3.76)\end{array}$ \\
\hline
\end{tabular}

Notes: This table reports the results of monthly time-series regressions for quintile portfolios grouped by the predicted probability of fund failure. The full sample is divided into two groups: on-shore funds and off-shore funds. Within each group, quintile portfolios are formed and time-series regressions are implemented. The time-series regressions are based on monthly portfolio returns from January 1997 to December 2012. Two definitions of hedge fund failure are considered: liquidation (Panel A) and LP_failure (Panel B). The return regressions are implemented after removing last two monthly returns for failed funds. 


\subsection{A Subsample without Extremely Small Funds}

Results from the previous sections suggest that failed funds are typically smaller in size than non-failed funds, and funds with high failure probability are also smaller in size than funds with low failure probability. Thus, there is a concern that the previously documented negative link between failure probability and future hedge fund returns is driven by extremely small hedge funds. To address this concern, I exclude the bottom $20 \%$ small funds based on average fund size. Using this sample, each fund's failure probability is newly estimated and quintile portfolios are formed every month. Then, I repeat the same time-series analysis to examine the relationship between failure probability and future fund returns. Table 12 shows that the negative effect of failure probability on future hedge fund returns is robust to the sample excluding extremely small hedge funds.

\subsection{Sub-period Analysis and Business Cycles}

In this subsection, I examine whether the negative link between failure probability and future fund returns depends on financial market conditions. If hedge funds with high failure risk underperform because of selling poorly performing assets at fire-sale prices to meet redemption requests by investors, the negative effect of failure probability on future fund returns is expected to be larger during market downturns than during market upturns.

To examine the time-varying effect of failure probability on future fund returns, I first conduct a simple subsample analysis. The sample period is divided into two subsample periods: 1997-2005 and 2006-2012. Results in Table 13 suggest that the negative effect of failure probability on future fund returns is robust to the two subsample periods. 


\section{Table 12: Exclude Bottom 20\% Small Funds}

\begin{tabular}{|c|c|c|}
\hline \multirow[b]{2}{*}{ Failure Risk } & \multicolumn{2}{|c|}{ Exclude bottom $20 \%$ small funds } \\
\hline & Raw Return & Alpha \\
\hline \multirow[t]{2}{*}{ Low } & 0.86 & 0.43 \\
\hline & $(5.46)$ & $(4.23)$ \\
\hline \multirow[t]{2}{*}{ Quin2 } & 0.78 & 0.37 \\
\hline & $(5.39)$ & $(4.59)$ \\
\hline \multirow[t]{2}{*}{ Quin3 } & 0.78 & 0.33 \\
\hline & $(4.56)$ & (4.03) \\
\hline \multirow[t]{2}{*}{ Quin4 } & 0.71 & 0.30 \\
\hline & $(4.13)$ & (3.65) \\
\hline \multirow[t]{2}{*}{ High } & 0.42 & 0.04 \\
\hline & (2.62) & $(0.49)$ \\
\hline \multirow[t]{2}{*}{$\mathrm{L}-\mathrm{H}$} & 0.44 & 0.39 \\
\hline & $(4.20)$ & $(4.36)$ \\
\hline
\end{tabular}

Panel B: Failure = LP_failure

\begin{tabular}{lll} 
& \multicolumn{2}{c}{ Exclude bottom 20\% small funds } \\
\cline { 2 - 3 } Failure Risk & Raw & \\
Low & 0.85 & Alpha \\
& $(5.74)$ & 0.44 \\
Quin2 & 0.77 & $(4.65)$ \\
& $(5.32)$ & 0.36 \\
Quin3 & 0.83 & $(4.23)$ \\
& $(4.71)$ & 0.37 \\
Quin4 & 0.74 & $(4.17)$ \\
& $(4.34)$ & 0.31 \\
High & 0.42 & $(3.76)$ \\
& $(2.41)$ & 0.05 \\
L $-\mathrm{H}$ & 0.43 & $(0.53)$ \\
& $(3.23)$ & 0.39 \\
\hline
\end{tabular}

Notes: The sample in this table excludes bottom $20 \%$ small funds based on average fund size. Using this sample, each fund's failure probability is newly estimated and quintile portfolios are formed every month. Then, I repeat the same time-series analysis to examine a relationship between failure probability and future hedge fund returns. The time-series regressions are based on monthly portfolio returns from January 1997 to December 2012. Two definitions of hedge fund failure are considered: liquidation (Panel A) and LP_failure (Panel B). The return regressions are implemented after removing last two monthly returns for failed funds. 
Table 13: Sub-Period Analysis: $1997-2005$ vs. 2006-2012

Panel A: Failure = Liquidation

\begin{tabular}{|c|c|c|c|c|}
\hline \multirow[b]{2}{*}{ Failure Risk } & \multicolumn{2}{|c|}{ (1) 1997-2005 } & \multicolumn{2}{|c|}{ (2) 2006-2012 } \\
\hline & Raw Return & Alpha & Raw Return & Alpha \\
\hline Low & $\begin{array}{l}1.10 \\
(5.43)\end{array}$ & $\begin{array}{l}0.46 \\
(4.12)\end{array}$ & $\begin{array}{l}0.60 \\
(2.24)\end{array}$ & $\begin{array}{l}0.40 \\
(2.33)\end{array}$ \\
\hline Quin2 & $\begin{array}{l}1.02 \\
(5.68)\end{array}$ & $\begin{array}{l}0.43 \\
(4.97)\end{array}$ & $\begin{array}{l}0.51 \\
(1.92)\end{array}$ & $\begin{array}{l}0.27 \\
(1.99)\end{array}$ \\
\hline Quin3 & $\begin{array}{l}0.93 \\
(4.00)\end{array}$ & $\begin{array}{l}0.29 \\
(2.97)\end{array}$ & $\begin{array}{l}0.45 \\
(1.64)\end{array}$ & $\begin{array}{l}0.20 \\
(1.54)\end{array}$ \\
\hline Quin4 & $\begin{array}{l}0.81 \\
(3.65)\end{array}$ & $\begin{array}{l}0.25 \\
(2.30)\end{array}$ & $\begin{array}{l}0.42 \\
(1.61)\end{array}$ & $\begin{array}{l}0.16 \\
(1.45)\end{array}$ \\
\hline High & $\begin{array}{l}0.49 \\
(2.39)\end{array}$ & $\begin{array}{l}-0.07 \\
(-0.61)\end{array}$ & $\begin{array}{l}0.19 \\
(0.70)\end{array}$ & $\begin{array}{l}-0.08 \\
(-0.66)\end{array}$ \\
\hline$L-H$ & $\begin{array}{l}0.61 \\
(6.36)\end{array}$ & $\begin{array}{l}0.53 \\
(5.99)\end{array}$ & $\begin{array}{l}0.41 \\
(2.08)\end{array}$ & $\begin{array}{l}0.48 \\
(3.11)\end{array}$ \\
\hline
\end{tabular}

Panel B: Failure = LP_failure

\begin{tabular}{|c|c|c|c|c|}
\hline \multirow[b]{2}{*}{ Failure Risk } & \multicolumn{2}{|c|}{ (1) 1997-2005 } & \multicolumn{2}{|c|}{ (2) 2006-2012 } \\
\hline & Raw Return & Alpha & Raw Return & Alpha \\
\hline Low & $\begin{array}{l}0.98 \\
(5.22)\end{array}$ & $\begin{array}{l}0.41 \\
(3.39)\end{array}$ & $\begin{array}{l}0.66 \\
(2.74)\end{array}$ & $\begin{array}{l}0.48 \\
(3.06)\end{array}$ \\
\hline Quin2 & $\begin{array}{l}0.95 \\
(5.57)\end{array}$ & $\begin{array}{l}0.37 \\
(4.08)\end{array}$ & $\begin{array}{l}0.52 \\
(2.10)\end{array}$ & $\begin{array}{l}0.30 \\
(2.20)\end{array}$ \\
\hline Quin3 & $\begin{array}{l}1.08 \\
(4.38)\end{array}$ & $\begin{array}{l}0.41 \\
(3.87)\end{array}$ & $\begin{array}{l}0.43 \\
(1.53)\end{array}$ & $\begin{array}{l}0.18 \\
(1.28)\end{array}$ \\
\hline Quin4 & $\begin{array}{l}0.82 \\
(3.68)\end{array}$ & $\begin{array}{l}0.21 \\
(1.93)\end{array}$ & $\begin{array}{c}0.43 \\
(1.52)\end{array}$ & $\begin{array}{l}0.15 \\
(1.16)\end{array}$ \\
\hline High & $\begin{array}{l}0.55 \\
(2.40)\end{array}$ & $\begin{array}{c}0.00 \\
(-0.01)\end{array}$ & $\begin{array}{l}0.20 \\
(0.69)\end{array}$ & $\begin{array}{l}-0.08 \\
(-0.59)\end{array}$ \\
\hline$L-H$ & $\begin{array}{l}0.43 \\
(2.83)\end{array}$ & $\begin{array}{l}0.41 \\
(3.82)\end{array}$ & $\begin{array}{l}0.45 \\
(1.91)\end{array}$ & $\begin{array}{l}0.56 \\
(2.99)\end{array}$ \\
\hline
\end{tabular}

Notes: This table reports the results of monthly time-series regressions for quintile portfolios grouped by the predicted probability of fund failure. The entire sample period (from January 1997 to December 2012) is divided into two sub-periods: 1997-2005 and 2006-2012. Two definitions of hedge fund failure are considered: liquidation (Panel A) and LP_failure (Panel B). The detailed explanations for portfolio formation and for time-series regressions are given in Table 3 and Table 5, respectively. The return regressions are implemented after removing last two monthly returns for failed funds. 
Next, I examine whether the negative link between failure probability and future fund returns is stronger during down periods. Down periods are defined in three different ways. First, down periods are the contraction periods by NBER business cycle reference dates. Second, down periods are the months in which a CFNAI-MA3 value is below -0.70.29) Third, down periods are the months when excess CRSP stock market returns are negative. Panel A of Table 14 reports the proportion of down periods for each measure and correlations between down period indicators. The proportion of down periods by NBER and CFNAI measures is low $(13.5 \%$ and $17.2 \%$, respectively) because the sample period includes a relatively small number of recessions. Furthermore, economic downturn indicators based on NBER and CFNAI measures are highly correlated (0.828), while correlations between stock market down periods and economic down periods are very low, 0.107 for NBER and 0.073 for CFNAI. The low correlation between stock market down periods and economic down periods suggests that a time-varying relationship between failure probability and future fund returns based on stock market downturns could be different from the same relationship based on economic downturns.

Using panel regressions, Table 14 (Panel B, C, and D) reports whether the negative link between failure probability and future fund returns is stronger during economic or stock market down periods. Overall, results from model (1 - NBER) and model (2 - CFNAI) suggest that the negative effect of failure probability on future fund returns does not become stronger during economic downturns. Results from model (3 - stock market) are mixed across the two definitions of hedge fund failure. Panel B (where failure means liquidation) shows no evidence of a stronger negative link between failure probability and future fund returns during stock market downturns. But, Panel C (where failure means LP_failure) provides evidence for a stronger negative link between failure probability and future fund returns during stock market downturns. Since Panel B and C provide mixed results, Panel D defines hedge fund failure by both liquidation and LP_failure, which

29) CFNAI-MA3 is a three-month moving average of monthly Chicago Fed National Activity Index. I collect data from https://www.chicagofed.org/research/data/cfnai/historical-data, and the historical data ending on December 2014 are used for this paper. A CFNAI-MA3 value below -0.70 following a period of economic expansion indicates an increasing likelihood that a recession has begun. 


\section{Table 14: Over the Business Cycle}

Panel A: Sample statistics of down period indicators

\begin{tabular}{lcccc} 
& & \multicolumn{3}{c}{ Correlation between down period indicators } \\
\cline { 3 - 5 } NBER & PBoportion of down periods & CFNAl & Stock Market \\
CFNAl & $13.5 \%$ & 1 & 0.828 & 0.107 \\
Stock Market & $17.2 \%$ & & 1 & 0.073 \\
\hline
\end{tabular}

Panel B: Failure = Liquidation

\begin{tabular}{|c|c|c|c|}
\hline Variable & Model 1 (NBER) & Model 2 (CFNAI) & Model 3 (Stock Market) \\
\hline Rank of failure prob & $\begin{array}{l}-0.13^{* * *} \\
(-4.80)\end{array}$ & $\begin{array}{l}-0.13^{* * *} \\
(-4.76)\end{array}$ & $\begin{array}{l}-0.08^{* *} \\
(-2.17)\end{array}$ \\
\hline Rankoffailureprob XI(down period) & $\begin{array}{c}0.14 \\
(1.36)\end{array}$ & $\begin{array}{c}0.14 \\
(1.61)\end{array}$ & $\begin{array}{c}0.00 \\
(-0.06)\end{array}$ \\
\hline |(down period) & $\begin{array}{l}-1.57^{* * *} \\
(-2.78)\end{array}$ & $\begin{array}{l}-1.03^{* *} \\
(-2.15)\end{array}$ & $\begin{array}{l}-2.88^{* * *} \\
(-8.87)\end{array}$ \\
\hline Control Variables & Yes & Yes & Yes \\
\hline \multicolumn{4}{|c|}{ Panel C: Failure = LP_failure } \\
\hline Variable & Model 1 (NBER) & Model 2 (CFNAI) & Model 3 (Stock Market) \\
\hline Rank of failure prob & $\begin{array}{l}-0.08^{* *} \\
(-2.33)\end{array}$ & $\begin{array}{l}-0.08^{* *} \\
(-2.34)\end{array}$ & $\begin{array}{l}0.02 \\
(0.52)\end{array}$ \\
\hline Rankoffailureprob $\times$ I(down period) & $\begin{array}{c}-0.04 \\
(-0.28)\end{array}$ & $\begin{array}{r}-0.01 \\
(-0.08)\end{array}$ & $\begin{array}{l}-0.21^{* * *} \\
(-2.95)\end{array}$ \\
\hline I(down period) & $\begin{array}{l}-1.00 * * \\
(-2.38)\end{array}$ & $\begin{array}{r}-0.57 \\
(-1.62)\end{array}$ & $\begin{array}{l}-2.24^{* * *} \\
(-7.49)\end{array}$ \\
\hline Control Variables & Yes & Yes & Yes \\
\hline \multicolumn{4}{|c|}{ Panel D: Failure = Liquidation and LP_failure } \\
\hline Variable & Model 1 (NBER) & Model 2 (CFNAI) & Model 3 (Stock Market) \\
\hline Rank of failure prob & $\begin{array}{l}-0.09^{* * *} \\
(-2.96)\end{array}$ & $\begin{array}{l}-0.09^{* * *} \\
(-3.11)\end{array}$ & $\begin{array}{l}0.03 \\
(0.79)\end{array}$ \\
\hline Rankoffailureprob XI(down period) & $\begin{array}{c}0.06 \\
(0.49)\end{array}$ & $\begin{array}{c}0.07 \\
(0.67)\end{array}$ & $\begin{array}{l}-0.23^{* * *} \\
(-3.57)\end{array}$ \\
\hline I(down period) & $\begin{array}{l}-1.32^{* * *} \\
(-2.98)\end{array}$ & $\begin{array}{l}-0.83^{* *} \\
(-2.21)\end{array}$ & $\begin{array}{l}-2.21^{* * *} \\
(-7.54)\end{array}$ \\
\hline Control Variables & Yes & Yes & Yes \\
\hline
\end{tabular}

Notes: This table reports the results from panel regressions that examine how a fund's failure risk affects its future returns over the business cycle. I(down market) takes the value of 1 if month $t$ is in a down market period, and 0 otherwise. In Model (1), down market periods are recessions by NBER. In Model (2), down market periods imply months in which a CFNAI-MA3 value is below -0.70 . In Model (3), down market periods are defined by negative excess stock market returns. Panel A reports sample statistics of down period indicators. The detailed explanations for the specification of panel regressions are given in Table 6. Control variables are from Model (3) in Table 6. Sample period is from January 1997 to December 2012. * indicates statistical significance at the $10 \%$ level, ** at the $5 \%$ level, and $* * *$ at the $1 \%$ level. Three definitions of hedge fund failure are considered: liquidation (Panel B), LP_failure (Panel C), and liquidation and LP_failure (Panel D). The return regressions are implemented after removing last two monthly returns for failed funds. 
could be interpreted as real failure. Based on the robust definition of hedge fund failure, Panel D supports the stronger negative link between failure probability and future fund returns during stock market downturns.

\section{Conclusion}

In this paper, I study the preconditions of hedge fund failures and how a hedge fund's failure probability affects its future returns using two different definitions of hedge fund failure. I model a hedge fund's failure probability using a dynamic logit regression and find that the fund's probability of failure increases as it has poor past performance, experiences fund outflows, takes high risks, is small in fund size, and has weak share restrictions.

Using the estimated probability of hedge fund failure, I document the negative link between failure probability and future hedge fund returns. To be robust, I remove the last two monthly returns of failed funds in every performance test. A quintile portfolio with the highest failure probability significantly underperforms a quintile portfolio with the lowest failure probability by $5 \sim 6 \%$ per year from 1997 to 2012. The results are robust to the definition of hedge fund failure and controlling for a large set of risk factors and fund characteristics. Furthermore, the negative link between failure probability and future fund returns is stronger within the funds with weak share restrictions. This suggests that hedge funds with weak share restrictions are concerned more about the threat of capital outflows than hedge funds with strong share restrictions, and they are more likely to liquidate some positions at fire-sale prices when their failure probability is high.

The negative effect of failure probability on future hedge fund returns is robust to macroeconomic uncertainty beta, several specifications of failure prediction model, investment styles, on-shore vs. off-shore funds, a sample excluding small hedge funds, and two subsample periods (1997-2005 vs. 2006-2012). Moreover, there is some evidence for a stronger negative effect of failure probability on future fund returns during stock market downturns. 


\section{References}

Aragon, G. (2007), "Share Restrictions and Asset Pricing: Evidence from the Hedge Fund Industry," Journal of Financial Economics, Vol. 83, Issue 1 , pp. 33-58.

Agarwal, V., and N. Naik (2004), "Risks and Portfolio Decisions Involving Hedge Funds," Review of Financial Studies, Vol. 17, Issue 1, pp. 63-98.

Asness, C., R. Krail, and J. Liew (2001), “Do Hedge Funds Hedge?” The Journal of Portfolio Management, Vol. 28, Issue 1, pp. 6-19.

Bali, T., S. Brown, and M. Caglayan (2011), "Do Hedge Funds' Exposures to Risk Factors Predict Their Future Returns?” Journal of Financial Economics, Vol. 101, Issue 1, pp. 36-68.

Bali, T., S. Brown, and M. Caglayan (2012), "Systematic Risk and the Cross Section of Hedge Fund Returns," Journal of Financial Economics, Vol. 106, Issue 1, pp. 114-131.

Bali, T., S. Brown, and M. Caglayan (2014), "Macroeconomic Risk and Hedge Fund Returns," Journal of Financial Economics, Vol. 114, Issue 1, pp. $1-19$.

Baquero, G., J. Ter Horst, and M. Verbeek (2005), "Survival, Look-Ahead Bias, and Persistence in Hedge Fund Performance," Journal of Financial and Quantitative Analysis, Vol. 40, Issue 3, pp. 493-517.

Brown, S., W. Goetzmann, and J. Park (2001), "Careers and Survival: Competition and Risk in the Hedge Fund and CTA Industry," The Journal of Finance, Vol. 56, Issue 5, pp. 1869-1886.

Campbell, J., J. Hilscher, and J. Szilagyi (2008), "In Search of Distress Risk," The Journal of Finance, Vol. 63, Issue 6, pp. 2899-2939.

Carhart, M. (1997), "On Persistence in Mutual Fund Performance," The Journal of Finance, Vol. 52, Issue 1, pp. 57-82.

Chan, N., M. Getmansky, S. Haas, and A. Lo (2006), "Do Hedge Funds Increase Systemic Risk?” Economic Review-Federal Reserve Bank of 
Atlanta, Vol. 91, Issue 4, pp. 49-80.

Chakraborty, I., and S. Ray (2010), "Effort, Risk and Walkaway under High Water Mark Contracts," Available at SSRN 1083089.

Cox, D. (1972), "Regression Models and Life-Tables," Journal of the Royal Statistical Society, Series B (Methodological), pp. 187-220.

Fama, E., and K. French (1993), "Common Risk Factors in the Returns on Stocks and Bonds," Journal of Financial Economics, Vol. 33, Issue 1, pp. $3-56$.

Fung, W., and D. Hsieh (2000), "Performance Characteristics of Hedge Funds and Commodity Funds: Natural vs. Spurious Biases," Journal of Financial and Quantitative Analysis, Vol. 35, Issue 3, pp. 291-307.

Fung, W., and D. Hsieh (2001), "The Risk in Hedge Fund Strategies: Theory and Evidence from Trend Followers," Review of Financial Studies, Vol. 14, Issue 2, pp. 313-341.

Fung, W., and D. Hsieh (2004), "Hedge Fund Benchmarks: A Risk-Based Approach," Financial Analysts Journal, Vol. 60, Issue 5, pp. 65-80.

Fung, W., and D. Hsieh (2009), "Measurement Biases in Hedge Fund Performance Data: An Update," Financial Analysts Journal, Vol. 65, Issue 3, pp. 36-38.

Fung, W., D. Hsieh, N. Naik, and T. Ramadorai (2008), "Hedge Funds: Performance, Risk, and Capital Formation," The Journal of Finance, Vol. 63, Issue 4, pp. 1777-1803.

Getmansky, M., A. Lo, and I. Makarov (2004), "An Econometric Model of Serial Correlation and Illiquidity in Hedge Fund Returns," Journal of Financial Economics, Vol. 74, Issue 3, pp. 529-609.

Grecu, A., B. Malkiel, and A. Saha (2007), "Why Do Hedge Funds Stop Reporting Performance?” The Journal of Portfolio Management, Vol. 34, Issue 1, pp. 119-126.

Kisgen, D. (2006), "Credit Ratings and Capital Structure," The Journal of Finance, Vol. 61, Issue 3, pp. 1035-1072. 
Kosowski, R., N. Naik, and M. Teo (2007), "Do Hedge Funds Deliver Alpha? A Bayesian and Bootstrap Analysis," Journal of Financial Economics, Vol. 84, Issue 1, pp. 229-264.

Liang, B. (2000), "Hedge Funds: The Living and the Dead," Journal of Financial and Quantitative Analysis, Vol. 35, Issue 3, pp. 309-326.

Liang, B., and H. Park (2010), "Predicting Hedge Fund Failure: A Comparison of Risk Measures," Journal of Financial and Quantitative Analysis, Vol. 45, Issue 1, pp. 199-222.

Lo, A., M. Getmansky, and S. Mei (2004), "Sifting through the Wreckage: Lessons from Recent Hedge-Fund Liquidations," Journal of Investment Management, Vol. 2, Issue 4, pp. 6-38.

Lunde, A., A. Timmermann, and D. Blake (1999), "The Hazards of Mutual Fund Underperformance: A Cox Regression Analysis," Journal of Empirical Finance, Vol. 6, Issue 2, pp. 121-152.

Malkiel, B., and A. Saha (2005), "Hedge Funds: Risk and Return," Financial Analysts Journal, Vol. 61, Issue 6, pp. 80-88.

McFadden, D. (1974), "The Measurement of Urban Travel Demand," Journal of Public Economics, Vol. 3, Issue 4, pp. 303-328.

Petersen, M. (2009), "Estimating Standard Errors in Finance Panel Data Sets: Comparing Approaches," Review of Financial Studies, Vol. 22, Issue 1 , pp. 435-480.

Sadka, R. (2010), "Liquidity Risk and the Cross-Section of Hedge-Fund Returns," Journal of Financial Economics, Vol. 98, Issue 1, pp. 54-71.

Satterthwaite, F. (1946), "An Approximate Distribution of Estimates of Variance Components," Biometrics bulletin, Vol. 2, Issue 6, pp. 110-114.

Shumway, T. (2001), "Forecasting Bankruptcy More Accurately: A Simple Hazard Model," The Journal of Business, Vol. 74, Issue 1, pp. 101-124.

Sirri, E., and P. Tufano (1998), "Costly Search and Mutual Fund Flows," The Journal of Finance, Vol. 53, Issue 5, pp. 1589-1622. 


\section{<Abstract in Korean>}

\section{헤지펀드 산업에서 실패확률과 \\ 미래수익률간의 횡단면 분석}

\section{김 정 민 *}

본고에서는 글로벌 자본시장에서 헤지펀드의 실패확률을 과거의 성과와 자금흐름 등을 바탕으로 예측한 후, 예측된 실패확률이 헤지펀드의 미래성과에 부정적으로 영향을 미친다는 것을 실증적으로 보였다. 구체적으로 1997년부터 2012년 기간동안 개별 헤지펀드들을 예측된 실패확률에 따라 다섯 그룹으로 나누었을 때, 실패확률이 가장 높은 그룹의 미래성과가 실패확률이 가장 낮은 그룹의 미래성과보다 연평균 5 6\%정도 낮다는 것을 보였다. 특히 투자자의 환매를 제한하는 조건이 약한 헤지펀드들의 경우 실패확률이 미래성과에 미치는 부정적 영향이 훨씬 큰 것으로 나타났다.

국내의 경우 헤지펀드 시장이 초기단계이지만 빠르게 성장하고 있으며 정부의 규제완화로 더욱 성장할 전망이다. 이러한 가운데 헤지펀드에 대한 해외사례를 통해 실패확률이 높은 헤지펀드를 미리 예측할 수 있는 모형을 구축하고, 실패확률이 높은 헤지펀드들의 성과 또한 예측하여 시스템위험을 줄이는 방법을 고려할 수 있다. 뿐만 아니라, 매각제한(lock-up)과 같은 투자자의 환매에 제약을 주는 계약을 통해서 “펀드런" 위험을 줄이는 것이 시스템위험을 더욱 줄일 수 있는 방법임을 시사한다.

핵심 주제어: 헤지펀드, 실패확률, 환매제한, 시스템위험

JEL Classification: G23

* 경제연구원 금융통화연구실 전문연구원

이 연구내용은 집필자 개인의견이며 한국은행의 공식견해와는 무관합니다. 따라서 본 논문의 내용을 보도하거나 인용할 경우에는 집필자명을 반드시 명시하여 주시기 바랍니다. 